JoANNA DOMINIAK

Uniwersytet im. Adama Mickiewicza, Poznań, Polska

\title{
Wpływ kryzysu gospodarczego na rynek usług otoczenia biznesu na przykładzie województwa wielkopolskiego
}

\author{
The impact of the economic crisis on the business \\ environment market based on the example \\ of Wielkopolska Voivodeship
}

\begin{abstract}
Streszczenie: Celem artykułu jest analiza funkcjonowania rynku usług otoczenia biznesu w województwie wielkopolskim w warunkach spowolnienia gospodarczego obserwowanego w Polsce po 2008 roku. Analiza ta uwzględnia zarówno podaż usług otoczenia biznesu, jak i popyt generowany przez przedsiębiorstwa korzystające z tych usług. Artykuł powstał w oparciu o badania terenowe przeprowadzone w województwie wielkopolskim. Ze względu na fakt, że instytucje i firmy otoczenia biznesu znajdują się przede wszystkim w dużych miastach, a te na podstawie analizy poziomu rozwoju społeczno-gospodarczego zostały zaliczone do obszarów wzrostu, badania ankietowe prowadzone były wyłącznie na zidentyfikowanych wcześniej obszarach wzrostu: w Poznaniu i powiecie poznańskim, Koninie, Kaliszu oraz Lesznie. Analiza strony popytowej otoczenia biznesu (przedsiębiorstw) uwzględnia także wyróżnione obszary stagnacji: powiaty słupecki, kaliski, pleszewski. Badanie ankietowe dotyczyło funkcjonowania instytucji i firm otoczenia biznesu, a także zapotrzebowania na usługi otoczenia biznesu ze strony przedsiębiorstw. W szczególności badanie zmierzało do: (1) analizy zmian zasięgu oddziaływania instytucji otoczenia biznesu oraz zmian zakresu świadczonych przez nie usług i ich sytuacji finansowej w dobie kryzysu, (2) identyfikacji zmian natężenia i zakresu relacji występujących między przedsiębiorstwami a instytucjami otoczenia biznesu w czasie kryzysu.

Artykuł prezentuje wyniki projektu badawczego: „Rozwój społeczno-gospodarczy a kształtowanie się obszarów wzrostu i stagnacji gospodarczej”, finansowanego przez Narodowe Centrum Nauki (N N306 791940), realizowanego w Zakładzie Analizy Regionalnej Uniwersytetu im. A. Mickiewicza w Poznaniu.
\end{abstract}

Abstract: The goal of this article is to analyse the operations of the business environment service
market in the Wielkopolska Voivodeship during the latest economic downturn observed in Poland after
2008. In this analysis, the supply of the business environment services and the demand generated by
companies taking advantage of these services have been taken into consideration. This article is based
on a field research conducted in the Wielkopolska Voivodeship. Bearing in mind that institutions and 
companies operating in a business environment are located predominantly in large cities which have been included into growth areas in the course of an analysis of the level of socio-economic development, questionnaire research was conducted exclusively in previously identified growth areas: the city of Poznań, Konin, Kalisz, Leszno, and Poznań county. An analysis of the demand in the business environment (companies) also considers the identified stagnation areas: Słupca, Kalisz and Pleszew counties. The questionnaire revolved around the operations of institutions and companies in a business environment, as well as a demand for business environment services on the part of companies. In particular, the research was aimed at: (1) analysing changes to the impact of business environment institutions and changes to the scope of services rendered by them and their financial situation in times of crisis; and (2) identifying the changes to the intensity and scope of relations between companies and business environment institutions in the time of economic downturn.

This article presents the results of the research project "Socio-economic development and the development of the areas of growth and economic stagnation", funded by the National Science Centre (N N306 791940 ) conducted at the Department of Regional Studies at the Adam Mickiewicz University in Poznan.

Słowa kluczowe: kryzys gospodarczy; otoczenie biznesu; usługi dla biznesu; województwo wielkopolskie

Keywords: economic crisis; business environment; business services; Wielkopolska Voivodeship

\section{WsTĘP}

Gospodarka rynkowa charakteryzuje się cyklicznością stanów koniunktury gospodarczej, w której okresy wzrostu gospodarczego przeplatają się z okresami dekoniunktury. Przyczyny występujących na przemian okresów wzrostu i recesji gospodarczej mogą być związane zarówno z uwarunkowaniami wewnętrznymi kraju i regionu, jak i tymi o charakterze zewnętrznym. Kryzys gospodarczy, zapoczątkowany pod koniec pierwszej dekady XXI w. załamaniem się rynków hipotecznych w Stanach Zjednoczonych, dotknął także polską gospodarkę, która jest silnie uzależniona od procesów dokonujących się w skali globalnej (Gorzelak, 2009). Mimo utrzymywania się w Polsce korzystnej - w porównaniu z innymi krajami europejskimi - sytuacji rynkowej, polskie firmy odczuwają w pewnym stopniu efekty kryzysowej sytuacji gospodarczej (Orłowski i in., 2010). W warunkach kryzysu - czy też wg niektórych - spowolnienia gospodarczego i niepewnej sytuacji większości krajów Unii Europejskiej zachodzą zmiany zachowań przedsiębiorstw (pracodawców). Spadek popytu na oferowane produkty wpływa z reguły na ograniczanie liczby pracowników, co dokonuje się na drodze redukcji zatrudnienia (Zioło, 2013). Towarzyszy temu pogorszenie kondycji ekonomicznej firm.

Właściwą drogą wyjścia z sytuacji kryzysowej wydaje się być intensyfikacja współpracy z instytucjami otoczenia biznesu oferującymi pomoc w zakresie doradztwa gospodarczego, szkoleń itp. Wobec szeroko toczącej się dyskusji na temat konsekwencji kryzysu ekonomicznego w różnych skalach i na różnych poziomach przestrzennych, istotną kwestią jest diagnoza wpływu kryzysu (spowolnienia gospodarczego) na rynek usług otoczenia biznesu. 
Rynek usług otoczenia biznesu rozumiany jest jako ogół wzajemnych stosunków między sprzedającymi, którzy oferują usługi otoczenia biznesu, czyli zgłaszają podaż (usługodawcy), a kupującymi, którzy wyrażają chęć zakupu tych usług, czyli zgłaszają popyt (usługobiorcy) (por. Daszkowska, 1998). Podaż usług otoczenia biznesu oferowana jest przez instytucje otoczenia biznesu i komercyjne firmy wykonujące usługi dla biznesu. Popyt generują przedsiębiorstwa korzystające $\mathrm{z}$ ich usług.

Celem artykułu jest analiza funkcjonowania rynku usług otoczenia biznesu w województwie wielkopolskim w warunkach spowolnienia gospodarczego obserwowanego w Polsce po 2008 roku. Analiza ta uwzględnia zarówno podaż usług otoczenia biznesu, jak i popyt generowany przez przedsiębiorstwa korzystające z tych usług. Artykuł powstał w oparciu o badania terenowe przeprowadzone w województwie wielkopolskim. Ze względu na fakt, że instytucje i firmy otoczenia biznesu lokalizowane są przede wszystkim w dużych miastach, a te na podstawie analizy poziomu rozwoju społeczno-gospodarczego zostały zaliczone do obszarów wzrostu, badania ankietowe prowadzone były wyłącznie na zidentyfikowanych wcześniej obszarach wzrostu: w Poznaniu i powiecie poznańskim, Koninie, Kaliszu, oraz Lesznie. Analiza strony popytowej otoczenia biznesu (przedsiębiorstw) uwzględnia także wyróżnione obszary stagnacji: powiaty słupecki, kaliski, pleszewski ${ }^{1}$.

Badanie zostało przeprowadzone techniką PAPI w okresie od czerwca do września 2013 roku. Łącznie badaniami objęto 32 instytucje otoczenia biznesu, 220 firm świadczących komercyjne usługi biznesowe oraz 737 przedsiębiorstw. Badanie ankietowe dotyczyło funkcjonowania instytucji i firm otoczenia biznesu, a także zapotrzebowania na usługi otoczenia biznesu ze strony przedsiębiorstw. W szczególności badanie zmierzało do: (1) analizy zmian zasięgu oddziaływania instytucji otoczenia biznesu oraz zmian zakresu świadczonych przez nie usług i ich sytuacji finansowej w dobie kryzysu, (2) identyfikacji zmian natężenia i zakresu relacji występujących między przedsiębiorstwami a instytucjami otoczenia biznesu w czasie kryzysu.

${ }^{1}$ Obszary wzrostu stanowią miejsca o relatywnie najwyższym poziomie rozwoju. Wyznaczono je na podstawie analizy skupień w oparciu o zestaw wskaźników poziomu rozwoju społeczno-gospodarczego (www.owisg.pl). Charakteryzują się one pozytywnymi tendencjami demograficznymi i wysoką jakością kapitału ludzkiego, wzmacnianą jeszcze możliwością korzystania z usług edukacyjnych na najwyższym poziomie. Rynek pracy tych obszarów cechuje duża różnorodność miejsc pracy i wysoki poziom przedsiębiorczości, skutkujący najwyższymi wskaźnikami samozatrudnienia. Uzyskiwane przychody zapewniają dobrą sytuację finansową podmiotom gospodarczym oraz pozwalają na zapewnienie wysokiego poziomu i warunków życia mieszkańcom.

Obszary stagnacji gospodarczej to regiony o relatywnie najniższym poziomie rozwoju. Wykazują negatywne tendencje demograficzne przy jednocześnie relatywnie niskim poziomie kapitału ludzkiego, który bardzo często podlega „drenażowi” przez obszary wzrostu. Rynek pracy tych rejonów bardzo często wykazuje cechy rynku monofunkcyjnego i charakteryzuje się wysokim poziomem bezrobocia. Ze względu na relatywnie niską jakość kapitału ludzkiego oraz powszechnie występujące braki infrastrukturalne gospodarka obszarów stagnacji cechuje się niską zdolnością do tworzenia innowacji oraz niskim poziomem elastyczności, co znajduje potwierdzenie w jej strukturze. Sytuacja ta prowadzi do przegrywania rywalizacji konkurencyjnej i stanowi przyczynę złej sytuacji finansowej podmiotów gospodarczych oraz niskiego poziomu i warunków życia mieszkańców.

Do obszarów wzrostu należą miasta na prawach powiatu: Poznań, Kalisz, Leszno, Konin (powiaty grodzkie) i powiat poznański (powiat ziemski), a obszarami stagnacji są powiaty ziemskie: kaliski, pleszewski i słupecki. 
ANALIZA PODAŻOWA OTOCZENIA BIZNESU

Otoczenie biznesu w szerokim tego słowa znaczeniu jest definiowane jako klimat sprzyjający prowadzeniu działalności gospodarczej i obejmuje wyposażenie instytucjonalne oraz środowisko innowacyjne (Chojnicki, 1999). W literaturze przedmiotu, zarówno z zakresu ekonomii, jak i regionalistyki, podkreśla się jego ważne znaczenie w procesie rozwoju gospodarczego, a w szczególności rozwoju małej i średniej przedsiębiorczości. Usługi otoczenia biznesu wykonywane są zarówno przez instytucje, jak i komercyjne firmy. Pojęcie instytucji otoczenia biznesu jest szerokie i generalnie obejmuje wszelkie instytucje zajmujące się wspieraniem działalności gospodarczej (Wach, 2008). Instytucje otoczenia biznesu stymulują lokalną przedsiębiorczość, inicjują działalność innowacyjną i umożliwiają transfery nowoczesnych technologii. Poprzez relację innowacja - przemysł przyczyniają się do rozwoju nowoczesnego przemysłu i wzrostu innowacyjności gospodarki (por. m.in. Aydalot i Keeble, 1988; Chmielewski i in., 2001; Doloreux, 2002; Lehner i in., 2006; Markiewicz, 2007; Matusiak, 2007; Todtling i in., 2008).

Instytucje otoczenia biznesu możemy podzielić na dwie główne grupy. Pierwsza z nich tworzy tzw. wyposażenie instytucjonalne regionu i obejmuje różnego rodzaju organizacje, agencje, fundacje i stowarzyszenia wspierające rozwój w skali lokalnej lub regionalnej (np. agencje rozwoju regionalnego) oraz organizacje o charakterze gospodarczym (czyli organizacje samorządu gospodarczego, organizacje pracodawców, profesjonalne). Druga grupa instytucji związana jest ze środowiskiem innowacyjnym. W jej skład wchodzą instytucje sfery badawczo-rozwojowej odpowiedzialne za generowanie innowacji oraz ośrodki pośredniczące $w$ transferze tych innowacji z nauki do gospodarki i ułatwiające proces ich komercjalizacji. Zalicza się do nich szeroko rozumiane ośrodki innowacji i przedsiębiorczości, takie jak centra transferu technologii, centra innowacji, parki technologiczne czy fundusze pożyczkowo-poręczeniowe.

Poza wymienionymi wyżej instytucjami, w sferze usług otoczenia biznesu działają także firmy komercyjne świadczące usługi biznesowe. Nowosielska (2000: 11) usługi dla biznesu utożsamia z grupą instytucji o charakterze komercyjnym, zajmujących się takimi obszarami, jak działalność prawnicza, rachunkowość, księgowość, badanie rynku i opinii publicznej, doradztwo w zakresie prowadzenia interesów, zarządzanie i reklama. Usługi dla biznesu sklasyfikowane zostały w sekcjach: pośrednictwo finansowe (J) PKD 2004 oraz obsługa nieruchomości i firm, nauka (K) PKD 2004. Po zmianie obowiązującej klasyfikacji i przejściu na PKD 2007, od 2009 roku podmioty te zostały zaklasyfikowane do następujących sekcji: informacja i komunikacja (J), działalność finansowa i ubezpieczeniowa (K), działalność związana z obsługą rynku nieruchomości (L), działalność profesjonalna, naukowa i techniczna (M) oraz działalność w zakresie usług administrowania i działalność wspierająca (N).

\section{Instytucje otoczenia biznesu}

Charakterystyka wpływu kryzysu gospodarczego na funkcjonowanie instytucji otoczenia biznesu, dokonywana w podziale na instytucje naukowe i organizacje gospodarcze, 
obejmuje następujące elementy: popyt, kondycję ekonomiczną, zatrudnienie, zasięg oddziaływania, ofertę oraz relacje z innymi instytucjami i klientami. Badane instytucje otoczenia biznesu podzielono na dwie grupy. Pierwszą z nich stanowi 21 instytucji o profilu naukowym i innowacyjnym tworzących środowisko innowacyjne Wielkopolski. Są to jednostki badawczo-rozwojowe i instytuty naukowe, ośrodki innowacji i przedsiębiorczości reprezentowane przez park naukowo-technologiczny, inkubatory przedsiębiorczości i ośrodki wspierania przedsiębiorczości oraz centrum innowacji, a także grupa spółek zajmujących się działalnością innowacyjną. Drugą grupę stanowi 11 instytucji gospodarczych, takich jak: izby gospodarcze, rzemieślnicze, cechy i stowarzyszenia (por. tab. 1 i 2 ).

Instytucje otoczenia biznesu reprezentujące usługi wyższego rzędu znajdują się zazwyczaj w dużych aglomeracjach miejskich, gdzie z jednej strony korzystają z wysoko wykwalifikowanej siły roboczej, a z drugiej mają odpowiedni popyt na swoje usługi, ze względu na dużą koncentrację działalności gospodarczej. Badane instytucje zlokalizowane były w największych miastach województwa wielkopolskiego - przede wszystkim w Poznaniu (25 instytucji), a także w Koninie (trzy instytucje), Kaliszu (dwie instytucje) oraz w strefie podmiejskiej aglomeracji poznańskiej (w gminie Suchy Las) (por. tab. 1 i 2).

Tab. 1. Wykaz badanych instytucji o profilu naukowym i innowacyjnym

\begin{tabular}{|c|l|l|}
\hline Lp. & \multicolumn{1}{|c|}{ Nazwa instytucji } & \multicolumn{1}{|c|}{ Siedziba } \\
\hline 1. & Fundacja Kaliski Inkubator Przedsiębiorczości & Kalisz \\
\hline 2. & Poznański Ośrodek Wspierania Przedsiębiorczości & Poznań \\
\hline 3. & Wielkopolskie Centrum Wspierania Inwestycji sp. z o.o. & Poznań \\
\hline 4. & Poznański Park Naukowo-Technologiczny Fundacji UAM & Poznań \\
\hline 5. & Uczelniane Centrum Innowacji i Transferu Technologii & Poznań \\
\hline 6. & $\begin{array}{l}\text { Centrum Innowacji, Rozwoju i Transferu Technologii } \\
\text { Politechniki Poznańskiej }\end{array}$ & Poznań \\
\hline 7. & Poznański Akademicki Inkubator Przedsiębiorczości & Poznań \\
\hline 8. & Instytut Biotechnologii Przemysłu Rolno-Spożywczego & Poznań \\
\hline 9. & Instytut Logistyki i Magazynowania & Poznań \\
\hline 10. & Instytut Obróbki Plastycznej & Poznań \\
\hline 11. & Wielkopolski Instytut Jakości & Poznań \\
\hline 12. & Przemysłowy Instytut Maszyn Rolniczych & Poznań \\
\hline 13. & Instytut Włókien Naturalnych i Roślin Zielarskich & Poznań \\
\hline 14. & Instytut Techniki Budowlanej & Poznań \\
\hline 15. & Instytut Technologii Drewna & Poznań \\
\hline 16. & Poznański Fundusz Poręczeń Kredytowych & Poznań \\
\hline 17. & ITTI sp. z o.o. & Poznań \\
\hline 18. & BIB Speed Capital sp. z o.o. & Poznań \\
\hline 19. & Speed Up Inqbator & Poznań \\
\hline 20. & Centrum Zaawansowanych Technologii sp. z o.o. & Poznań \\
\hline 21. & Nickel Technology Park & Suchy Las \\
\hline
\end{tabular}

Źródło: opracowanie własne 
Tab. 2. Wykaz badanych instytucji gospodarczych

\begin{tabular}{|c|l|l|}
\hline Lp. & \multicolumn{1}{|c|}{ Nazwa instytucji } & Siedziba \\
\hline 1. & Zrzeszenie Handlu Gastronomii i Usług w Koninie & Konin \\
\hline 2. & Cech Rzemiosł Różnych & Konin \\
\hline 3. & Koninska Izba Gospodarcza & Konin \\
\hline 4. & Izba Rzemieślnicza w Kaliszu & Kalisz \\
\hline 5. & Polska Izba Gospodarcza Importerów, Eksporterów i Kooperacji & Poznań \\
\hline 6. & Wielkopolska Izba Rzemieślnicza w Poznaniu & Poznań \\
\hline 7. & Wielkopolska Izba Rolnicza & Poznań \\
\hline 8. & Stowarzyszenie im. Eugeniusza Kwiatkowskiego & Poznań \\
\hline 9. & Stowarzyszenie Gmin i Powiatów Wielkopolski & Poznań \\
\hline 10. & Wielkopolska Izba Przemysłowo-Handlowa & Poznań \\
\hline 11. & Związek Pracodawców Prywatnych & Poznań \\
\hline
\end{tabular}

Źródło: opracowanie własne

W strukturze badanych instytucji wg wielkości zatrudnienia dominowały instytucje zatrudniające 10-50 osób (53\%) oraz powyżej 50 osób (33\%). Jedynie 14\% stanowiły instytucje zatrudniające do dziewięciu pracowników. Organizacje gospodarcze cechowały się niższym zatrudnieniem niż instytucje środowiska innowacyjnego. Aż w siedmiu na dziesięciu badanych instytucji zatrudnionych było poniżej dziewięciu pracowników (por. ryc. 1).

\section{Zasięg oddziaływania}

Największa grupa badanych instytucji (33\%) zadeklarowała krajowy zasięg oddziaływania. Nieco mniej wskazań miało województwo wielkopolskie (18\%) i powiat poznański (16\%) - dotyczyło to organizacji zlokalizowanych w Poznaniu. Zasięg oddziaływania 16\% badanych instytucji wykraczał poza granice kraju. W przypadku instytucji gospodarczych (pięć) połowa badanych jako zasięg oddziaływania wskazała na województwo wielkopolskie, a cztery - na kraj. W odniesieniu do instytucji środowiska innowacyjnego było odwrotnie - nieco wyższy był udział organizacji o krajowym zasięgu oddziaływania.

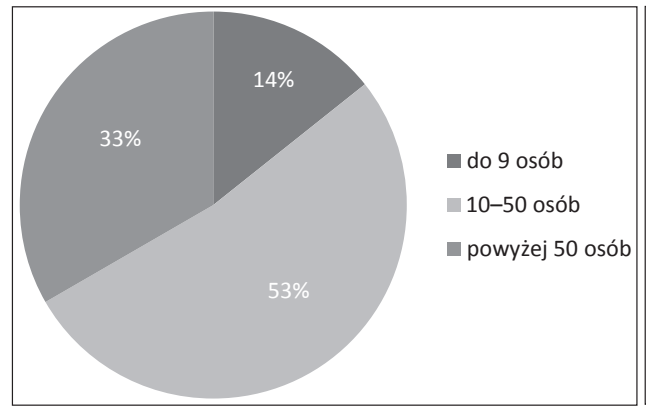

Ryc. 1. Struktura badanych instytucji wg wielkości zatrudnienia Źródło: opracowanie własne

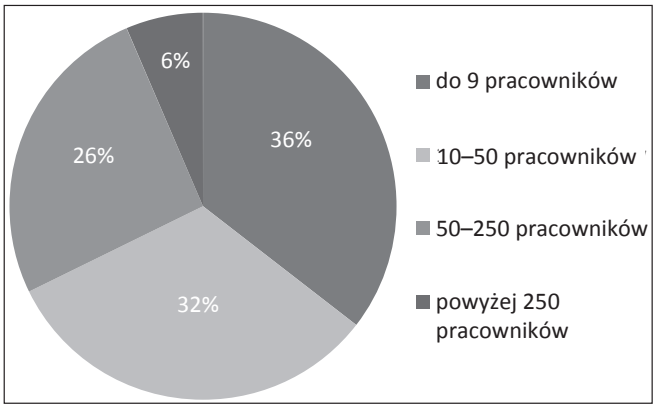

Ryc. 2. Struktura wielkościowa odbiorców usług badanych instytucji 
W przypadku zdecydowanej większości badanych instytucji (67\%) nie odnotowano znaczących zmian w zasięgu ich oddziaływania w ostatnich 10 latach. Nieco ponad 30\% badanych zadeklarowało rozszerzenie zasięgu oddziaływania, żadna z organizacji nie odnotowała jego zmniejszenia. Zwiększenie zasięgu oddziaływania dotyczyło najczęściej zmian z poziomu regionalnego na poziom krajowy (np. Poznański Park Naukowo-Technologiczny) oraz z poziomu krajowego na zagraniczny (np. Instytut Logistyki i Magazynowania).

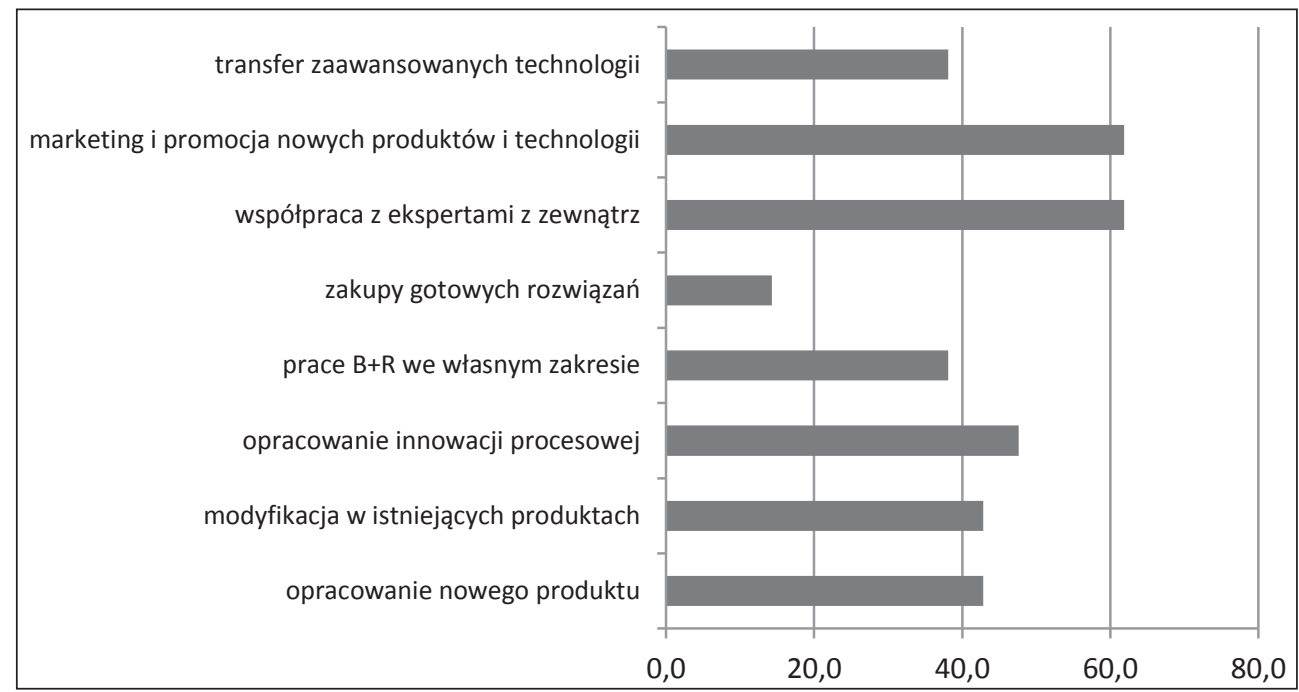

Ryc. 3. Aktywność innowacyjna badanych instytucji środowiska innowacyjnego (w \%)

Źródło: opracowanie własne

Badane instytucje środowiska innowacyjnego można podzielić na dwie grupy. Pierwsza $\mathrm{z}$ nich to instytuty naukowe, jednostki badawczo-rozwojowe zajmujące się generowaniem innowacji (np. Instytut Biotechnologii Przemysłu Rolno-Spożywczego, Instytut Obróbki Plastycznej, Przemysłowy Instytut Maszyn Rolniczych, Instytut Włókien Naturalnych i Roślin Zielarskich). Stanowią one pierwsze ogniwo na drodze nowego produktu lub technologii ze sfery nauki do gospodarki.

Druga grupa instytucji to ośrodki dające wsparcie transferowi technologii (Centrum Innowacji, Rozwoju i Transferu Technologii Politechniki Poznańskiej, Uczelniane Centrum Innowacji i Transferu Technologii), wspierające innowacyjną przedsiębiorczość pod względem finansowym (BIB Speed Capital sp. z o.o., Poznański Fundusz Poręczeń Kredytowych), szkoleniowym i doradczym (Centrum Zaawansowanych Technologii sp. z o.o., ITTI sp. z o.o., Poznański Ośrodek Wspierania Przedsiębiorczości). To organizacje pośredniczące między nauką a praktyką gospodarczą, ułatwiające komercjalizację nowych produktów i technologii, niezbędne do wzrostu innowacyjności gospodarki regionu.

Aktywność innowacyjna badanych instytucji przedstawiała się następująco. Ponad 60\% badanych organizacji środowiska innowacyjnego prowadziło działalność przy współpracy 
ekspertów zewnętrznych, a mniej niż 40\% prowadziło działalność B+R we własnym zakresie. Wśród badanych instytucji $42 \%$ opracowało nowy produkt, tyle samo opracowało modyfikację produktu, a 48\% - innowacje o charakterze technologicznym. Działalność w zakresie transferu nowych technologii prowadziło $38 \%$ instytucji, a działalność marketingową i promocyjną w zakresie nowych produktów i technologii - $62 \%$ (por. ryc. 3 ).

W przypadku organizacji gospodarczych cele działalności koncentrowały się wokół reprezentowania interesów członków na forum krajowym oraz wszechstronnego wsparcia ich działalności gospodarczych. Organizacje te prowadzą również działalność szkoleniową, (także nadzór nad szkoleniami), doradczą oraz inicjującą współpracę zagraniczną.

\section{Powiązania i współpraca}

Niemal wszystkie badane instytucje środowiska innowacyjnego współpracowały z innymi organizacjami naukowymi, w tym poznańskimi szkołami wyższymi, realizując wspólne projekty badawcze, organizując seminaria i konferencje, wymieniając doświadczenia i wiedzę (por. ryc. 4).

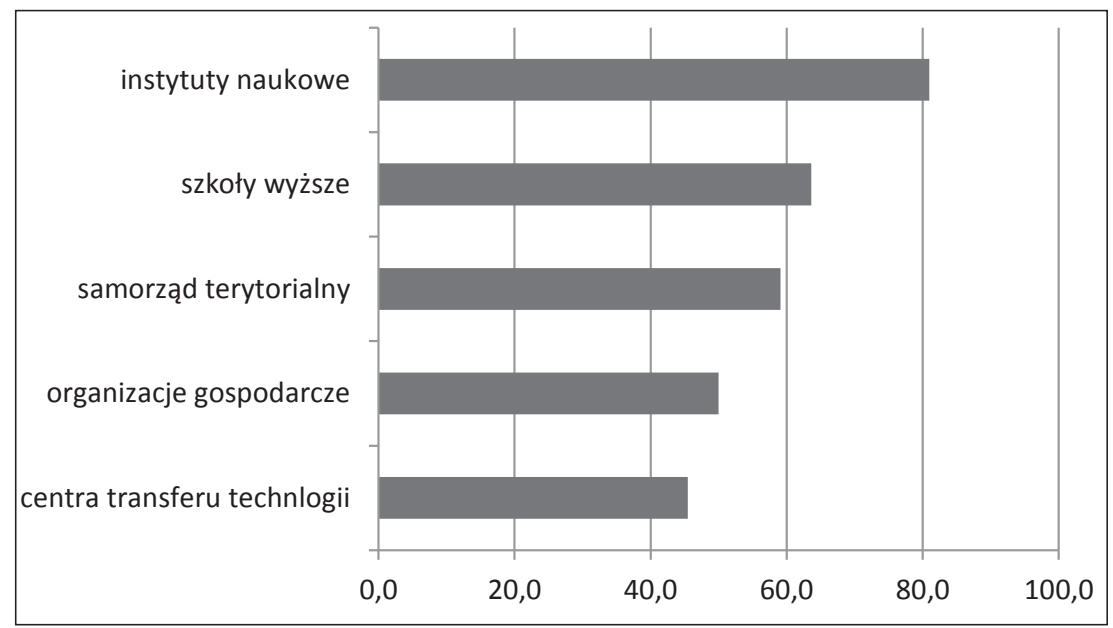

Ryc. 4. Odsetek instytucji środowiska innowacyjnego współpracujących z instytucjami otoczenia biznesu (IOB) (w \%)

Źródło: opracowanie własne

Nieco ponad połowa badanych instytucji współpracowała także z centrami transferu technologii, organizacjami gospodarczymi oraz samorządem. Organizacje gospodarcze z kolei współpracowały głównie z samorządem gospodarczym i samorządem terytorialnym (por. ryc. 5). 


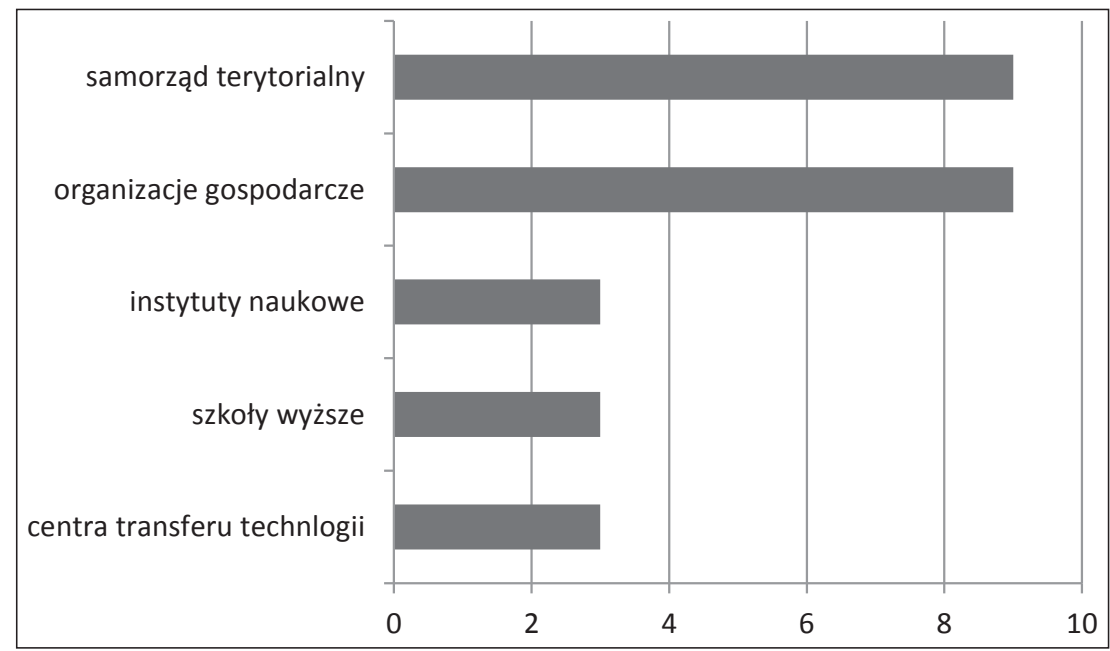

Ryc. 5. Odsetek organizacji gospodarczych współpracujących z IOB (w \%)

Źródło: opracowanie własne

\section{Wpływ kryzysu gospodarczego}

Na pytanie o wpływ kryzysu gospodarczego $47 \%$ ankietowanych instytucji odpowiedziało, że nie odczuło zmian $\mathrm{w}$ funkcjonowaniu $\mathrm{w}$ związku z procesem spowolnienia gospodarczego, jakie miało miejsce w 2008 roku. Jednocześnie w przypadku 40\% instytucji zaistniały kryzys gospodarczy spowodował znaczące zmiany (por. ryc. 6).

Zdecydowanie silniej odczuły wpływ kryzysu organizacje gospodarcze. Aż połowa $\mathrm{z}$ nich odpowiedziała $\mathrm{w}$ tym przypadku twierdząco. Badane organizacje zrzeszają najczęściej mikro- i małe przedsiębiorstwa, które silnie zareagowały na spowolnienie gospodarcze. W przypadku instytucji środowiska innowacyjnego odsetek ten wynosił jedynie 35\%. Wśród tych instytucji, które odczuły wpływ kryzysu gospodarczego, $64 \%$ odnotowało ograniczenie liczby zamówień. Ograniczenie to odnotowało $75 \%$ instytucji środowiska innowacyjnego i tylko dwie organizacje gospodarcze (20\%). Jednocześnie w przypadku obu typów instytucji ok. $1 / 4$ nie odnotowała zmian w popycie, a jedna zanotowała nawet wzrost zainteresowania swoimi usługami.

Połowa badanych instytucji nie odczuła zmian kondycji ekonomicznej pod wpływem kryzysu gospodarczego. Nieco mniej organizacji (42\%) deklarowało pogorszenie sytuacji finansowej, a jedynie $8 \%$ zanotowało jej poprawę. Instytucje środowiska innowacyjnego także i w tym przypadku okazały się nieco mniej wrażliwe na kryzys gospodarczy. W ich przypadku tylko $36 \%$ odnotowało pogorszenie kondycji ekonomicznej, a pozostałe $64 \%$ nie odczuło w tym względzie znaczących zmian. Inaczej sytuacja prezentowała się w odniesieniu do instytucji gospodarczych. Aż połowa z nich odczuła pogorszenie kondycji ekonomicznej. 


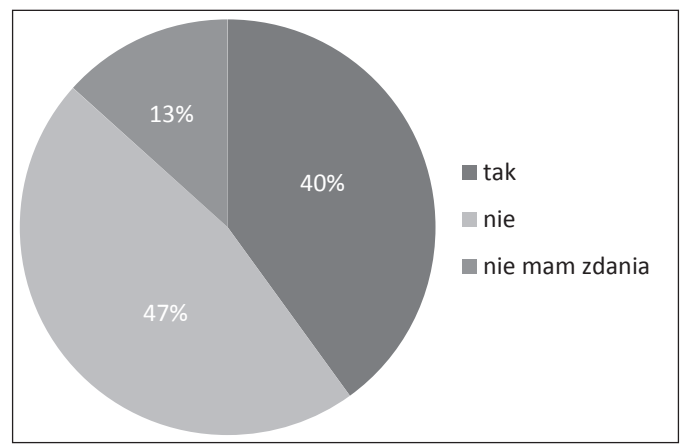

instytucje otoczenia biznesu ogółem

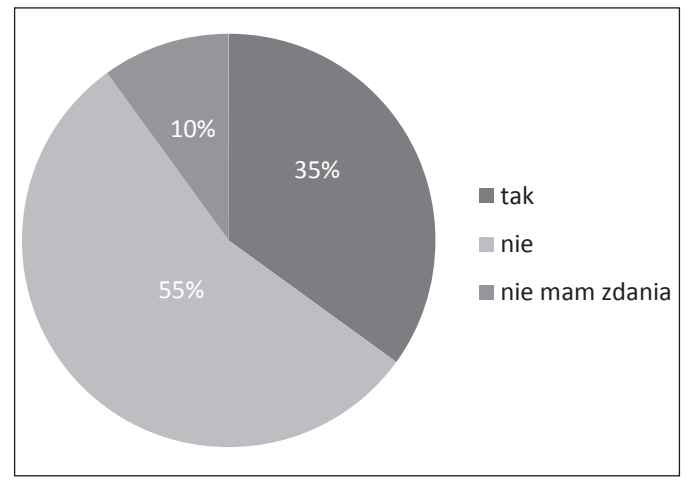

instytucje środowiska innowacyjnego

Ryc. 6. Odpowiedzi ankietowanych instytucji na pytanie o wpływ kryzysu gospodarczego

Źródło: opracowanie własne

Redukcja zatrudnienia związana z kryzysem gospodarczym dotknęła 46\% badanych instytucji, przy $36 \%$, które nie odnotowały zmian w tym zakresie. Jednocześnie 18\% (dwie instytucje, po jednej z grupy organizacji gospodarczych i instytucji środowiska innowacyjnego) zwiększyły swoje zatrudnienie. W tym przypadku nie odnotowano znaczących różnic między badanymi typami.

W zasadzie nie odnotowano znaczącego wpływu kryzysu gospodarczego na zasięg oddziaływania badanych instytucji. Tylko jedna z nich - Instytut Logistyki i Magazynowania - zadeklarowała zwiększenie zasięgu oddziaływania.

Kryzys ekonomiczny nie spowodował również znaczących zmian w przypadku ofert usług badanych instytucji. 70\% z nich nie zmieniło pod jego wpływem zakresu świadczonych usług. Tylko 10\% organizacji zmieniło ofertę, próbując dostosować ją do nowych warunków, a 20\% badanych postanowiło ograniczyć ofertę usługową w dobie kryzysu. Zmiany i ograniczenie ofert dotyczyły przede wszystkim organizacji gospodarczych (por. ryc. 7).

Kryzys gospodarczy spowodował zmiany w sieci współpracy niektórych badanych instytucji otoczenia biznesu. W przypadku pięciu z nich nawiązano współpracę z nowymi instytucjami. Także pięć badanych organizacji rozszerzyło dotychczasowy zakres współpracy. Jednak $10 \mathrm{z}$ nich nie odnotowało znaczących zmian $\mathrm{w}$ relacjach z innymi instytucjami otoczenia biznesu. 


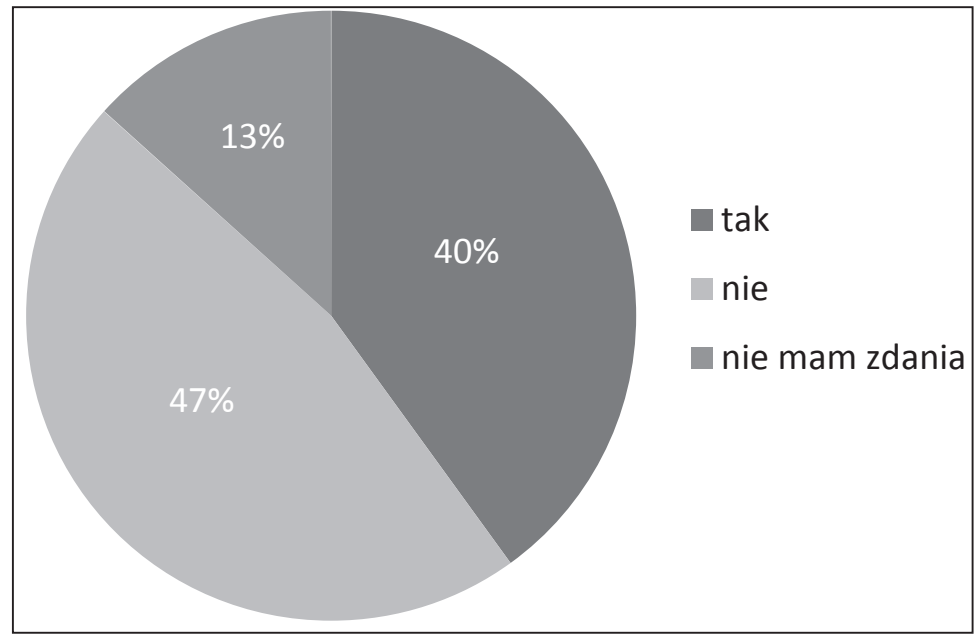

popyt

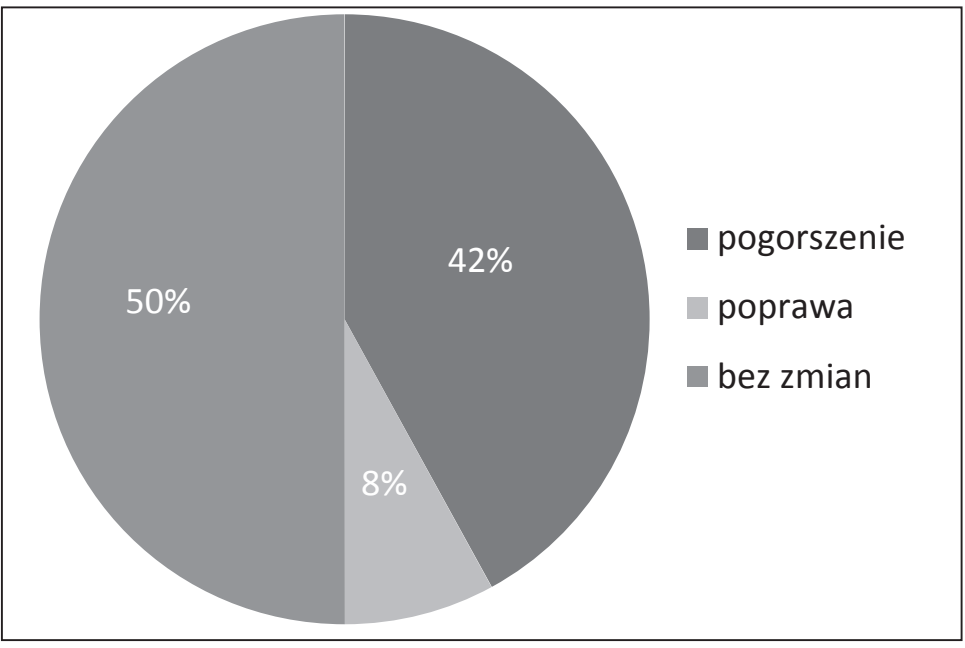

kondycja ekonomiczna

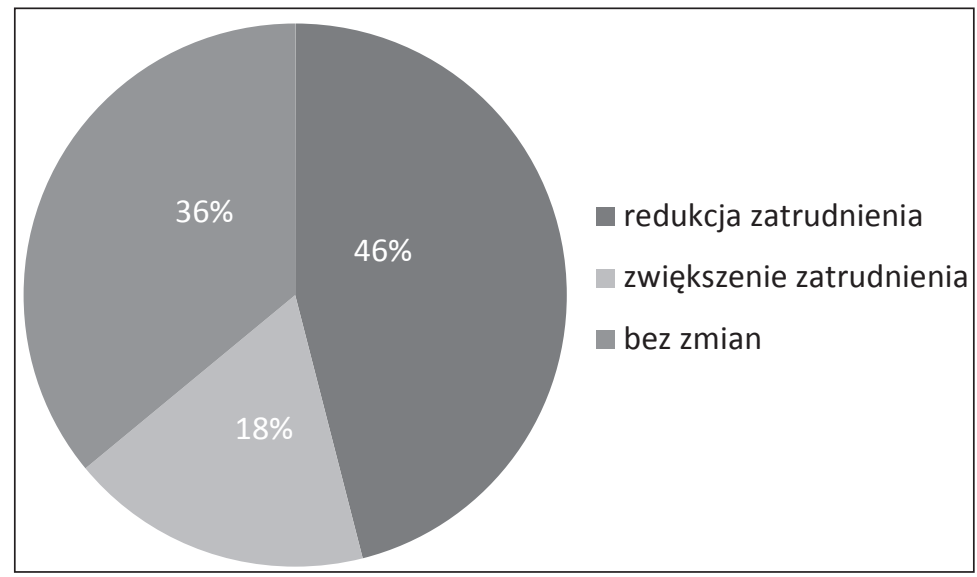

zatrudnienie 


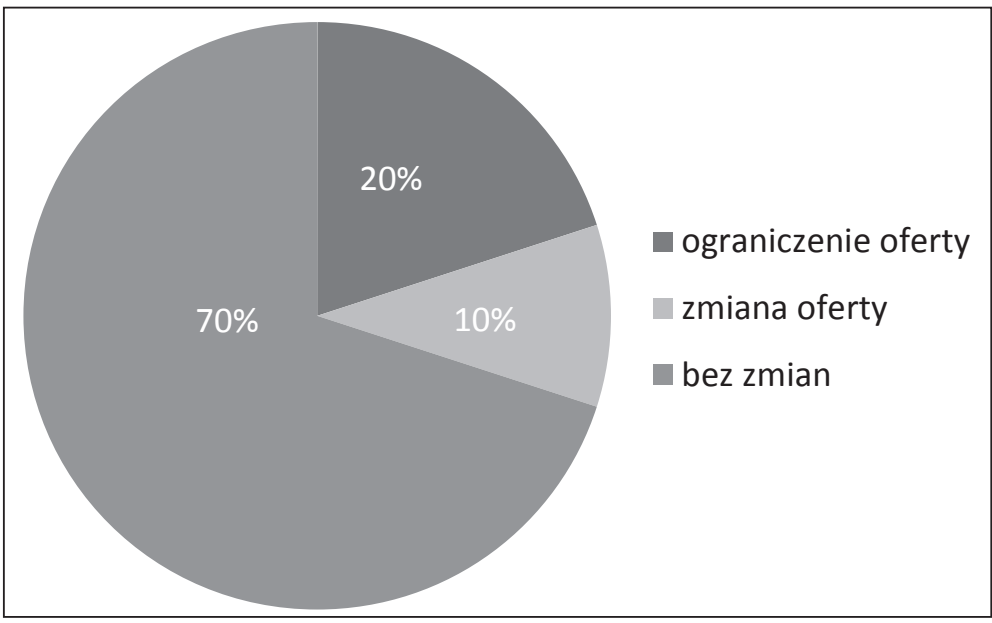

oferta usług

Ryc. 7. Wpływ kryzysu na popyt, kondycję ekonomiczną, zatrudnienie i ofertę usług

Źródło: opracowanie własne

KOMERCYJNE FIRMY OFERUJĄCE USŁUGI DLA BIZNESU

Charakterystyka funkcjonowania komercyjnych firm świadczących usługi biznesowe (zarejestrowanych w ramach sekcji J i K PKD 2004) dotyczyła przede wszystkim firm sektora bankowego i ubezpieczeniowego, agencji pośrednictwa nieruchomościami, kancelarii prawnych, biur podatkowych i rachunkowych, doradztwa technicznego i gospodarczego, marketingu i reklamy, tłumaczeń (por. ryc. 8). Analiza prowadzona była zarówno w układzie - obszary wzrostu razem, jak i w podziale na poszczególne jednostki. Układ analizy obejmuje następujące elementy: wpływ kryzysu na popyt, kondycję ekonomiczną, zatrudnienie, zasięg oddziaływania, ofertę, relacje z innymi firmami i instytucjami oraz klientami.

Zdecydowana większość badanych firm wykonujących usługi dla biznesu to mikroprzedsiębiorstwa, zatrudniające do dziewięciu pracowników (niemal 80\%). Zatrudnienie 17\% badanych organizacji mieściło się w przedziale 10-50 osób, a jedynie 4\% firm liczyło ponad 50 pracowników. Największy udział mikroprzedsiębiorstw odnotowano w Kaliszu oraz w strefie peryferyjnej Poznania (powiecie poznańskim). Największym udziałem dużych firm świadczących usługi biznesowe cechował się Poznań (7\%) (por. ryc. 9). 


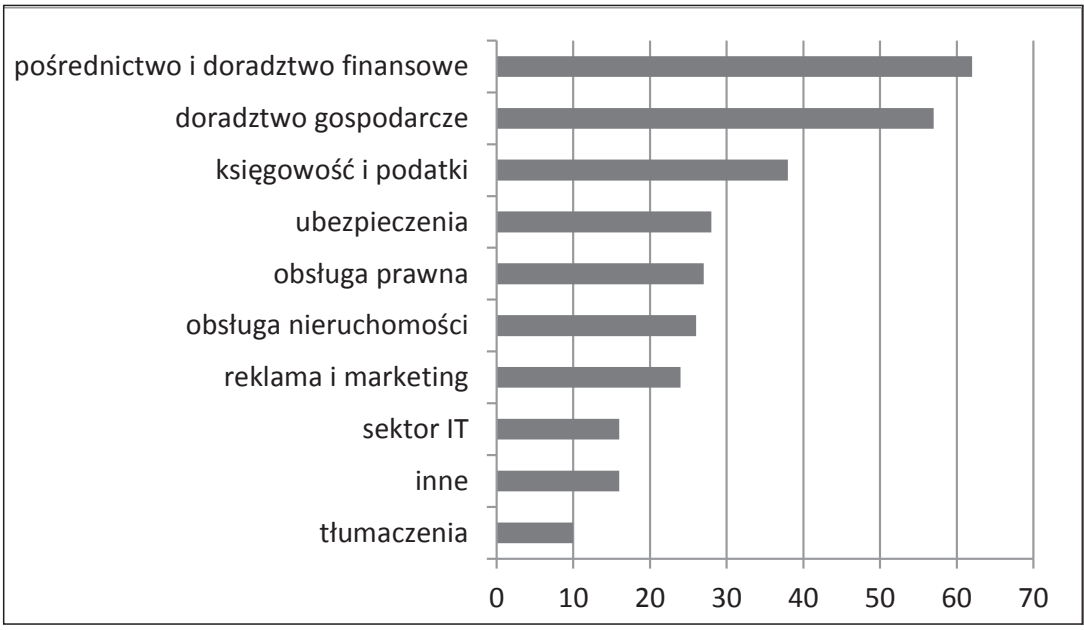

Ryc. 8. Rodzaj usług świadczonych przez badane firmy (w \%)

Źródło: opracowanie własne

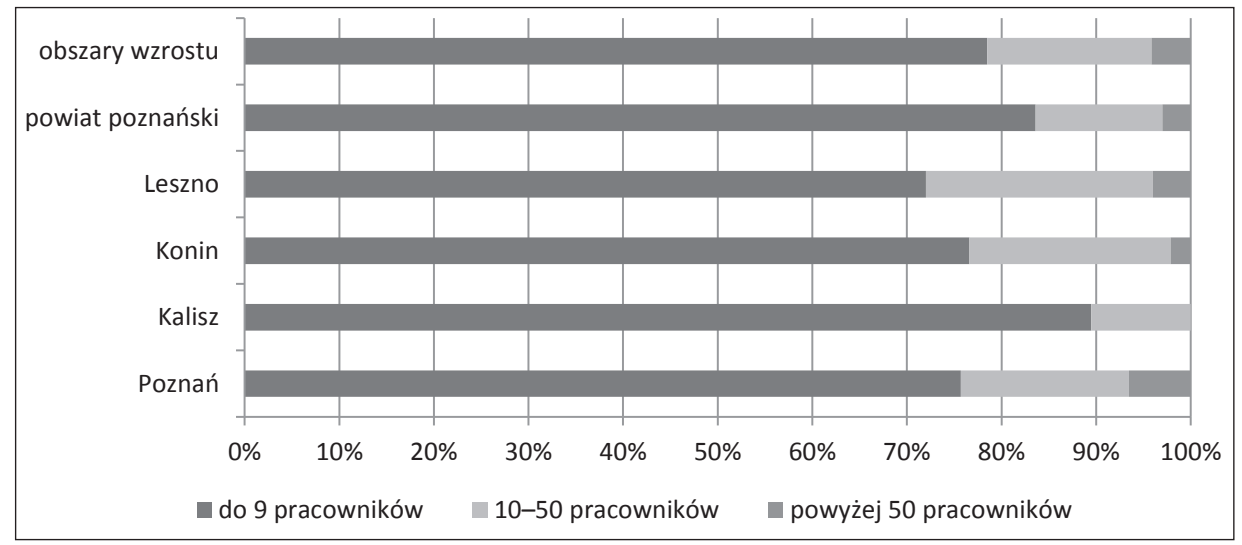

Ryc. 9. Wielkość zatrudnienia badanych firm

Źródło: opracowanie własne

\section{Charakterystyka klientów}

Wśród klientów firm wykonujących usługi dla biznesu dominowały małe i średnie przedsiębiorstwa. Ok. 40\% badanych deklarowało, że z ich usług korzystają przede wszystkim mikroprzedsiębiorstwa, zatrudniające do dziewięciu pracowników. Podobny odsetek firm (39\%) świadczy usługi organizacjom zatrudniającym od 10 do 50 osób. Zdecydowanie mniej firm wykonuje usługi dla biznesu przedsiębiorstwom większym, zatrudniającym 
50-250 osób (17\%) i powyżej 250 osób (4\%). W odniesieniu do struktury wielkościowej klientów odnotowano różnice pomiędzy poszczególnymi badanymi obszarami. W przypadku Poznania i powiatu poznańskiego zaobserwowano wyższy udział większych organizacji, natomiast w przypadku Konina, Kalisza i Leszna - wśród klientów firm wykonujących usługi dla biznesu dominowały mikroprzedsiębiorstwa.

\section{Zasięg oddziaływania}

Ok. 18\% badanych firm wykonywało usługi dla przedsiębiorstw z całego kraju, 23\% cechowało się regionalnym zasięgiem sprzedaży. Pozostałe firmy świadczyły swoje usługi na szczeblu lokalnym, na terenie powiatu lub w macierzystym mieście (gminie) - 54\%. Nieliczne przedsiębiorstwa (5\%) obsługiwały klientów także spoza Polski (por. ryc. 10). Na przykładzie aglomeracji poznańskiej widać, że firmy zlokalizowane w dużych miastach, będących rdzeniami aglomeracji miejskich, charakteryzują się nieco większym zasięgiem oddziaływania niż przedsiębiorstwa w gminach strefy podmiejskiej. Więcej firm z Poznania deklarowało zasięg regionalny (w samym Poznaniu - 10\%, a w powiecie poznańskim - 5\%) i ponadregionalny, a także krajowy (odpowiednio 17\% i 16\%) i międzynarodowy (5\% i 3\%). W przypadku zdecydowanej większości firm zasięg oddziaływania miał charakter stały i nie ulegał znaczącym zmianom. Jedynie 35\% badanych odnotowało zwiększenie zasięgu oddziaływania, a jego zmniejszenia nie stwierdzono wcale.

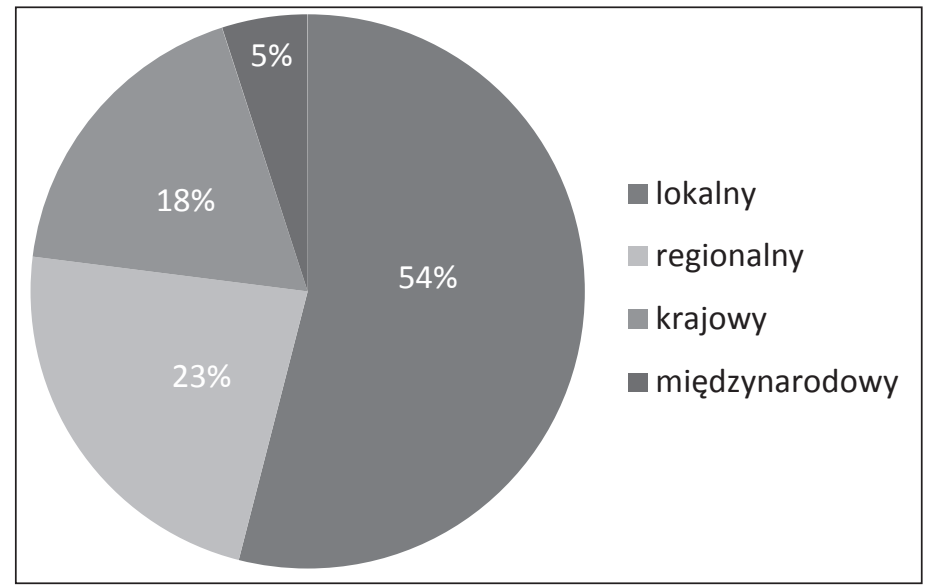

Ryc. 10. Zasięg oddziaływania badanych firm

Źródło: opracowanie własne

\section{Powiązania i współpraca}

Jedynie nieco ponad 19\% badanych firm współpracowało z przedsiębiorstwami z tej samej branży. Częściej współpracowano z firmami świadczącymi inne usługi biznesowe $(33 \%)$. Celem takiej współpracy było tworzenie ofert uzupełniających się usług dla kompleksowej obsługi klienta. Dotyczyło to np. ubezpieczeń kredytów (współpraca firm 
ubezpieczeniowych i pośrednictwa finansowego) czy pełnej oferty doradztwa dla firm (doradztwo gospodarcze i marketingowe, personalne itp).

Podobnie przedstawiała się kwestia współpracy z instytucjami otoczenia biznesu. Współpracowało z nimi ok. 25\% badanych firm. Odsetek ten różnił się w układzie obszarów wzrostu. Najwięcej przedsiębiorstw współpracowało z IOB w Poznaniu (30\%). Na pozostałych terenach odsetek ten oscylował w granicach $20 \%$ (por. ryc. 11).

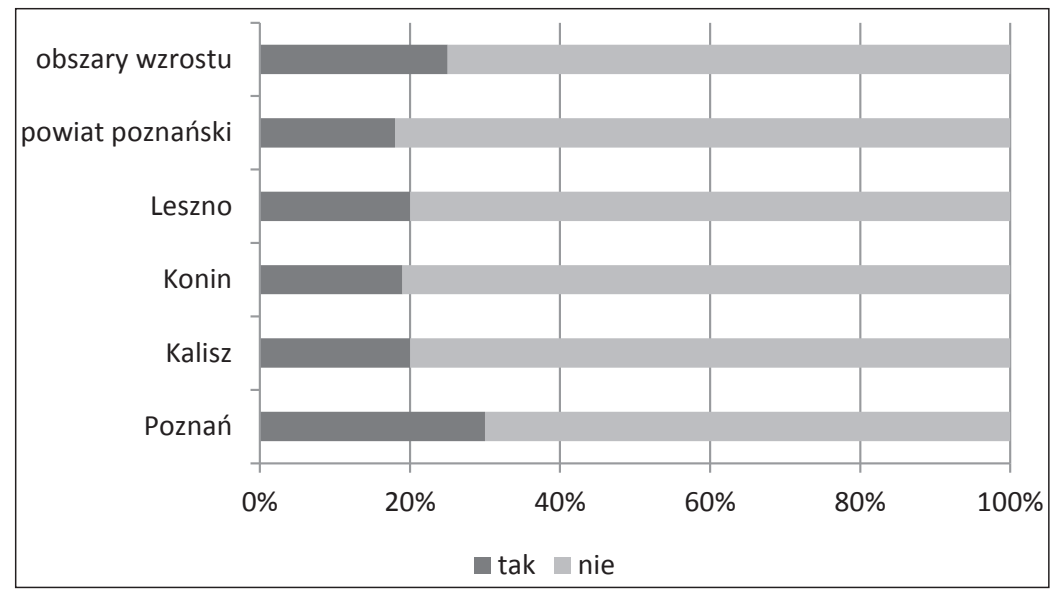

Ryc. 11. Współpraca z instytucjami otoczenia biznesu

Źródło: opracowanie własne

Te firmy, które współpracowały z instytucjami otoczenia biznesu, pozytywnie oceniły tę współpracę, w tym ponad połowa (54\%) - raczej pozytywnie, a 23\% - bardzo pozytywnie. Negatywnie oceniło współpracę jedynie 2\% firm. 21\% respondentów nie miało w tej kwestii zdania (por. ryc. 12).

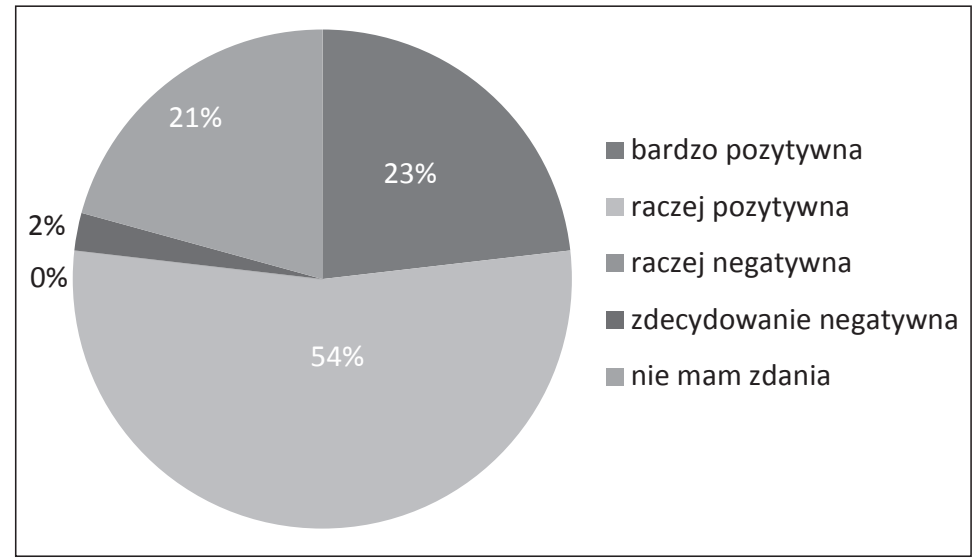

Ryc. 12. Ocena współpracy z instytucjami otoczenia biznesu

Źródło: opracowanie własne 


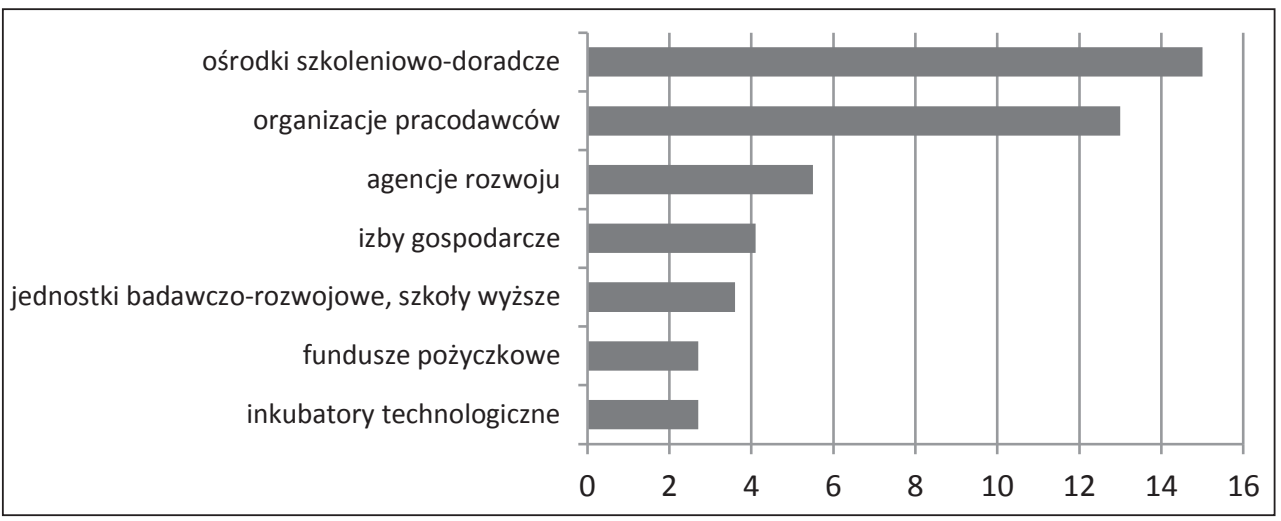

Ryc. 13. Odsetek firm współpracujących z poszczególnymi typami instytucji otoczenia biznesu (w \%) Źródło: opracowanie własne

Najczęściej firmy współpracowały z ośrodkami szkoleniowo-doradczymi (15\%) oraz organizacjami gospodarczymi (13\%). Zdecydowanie mniejszy odsetek przedsiębiorstw współpracował z agencjami rozwoju (ok. 5\%), sferą badawczo-rozwojową (3\%), jeszcze mniejszy z instytucjami parabankowymi oraz ośrodkami innowacji (inkubartorami, centrami transferu technologii, parkami technologicznymi) (por. ryc. 13).

\section{Wpływ kryzysu}

Dokładnie połowa badanych firm świadczących usługi biznesowe odczuła skutki kryzysu ekonomicznego zapoczątkowanego w 2008 roku. Ok. 29\% ankietowanych nie odnotowało znaczących zmian w wyniku kryzysu, a 21\% nie miało w tej kwestii zdania. Wyniki te zbliżone są do wyników badań prowadzonych w województwie małopolskim (Bereza, 2013) i potwierdzają, iż przedsiębiorstwa polskie, mimo że dotknięte zostały oddziaływaniem kryzysu gospodarczego, nie zareagowały tak gwałtowne i negatywne jak w przypadku innych państw europejskich. Najsilniej wpływ kryzysu odczuły firmy zlokalizowane w Kaliszu (aż 63\% z nich na pytanie, czy firma odczuła wpływ kryzysu, odpowiedziało twierdząco). Najmniejszy udział przedsiębiorstw odczuwających skutki kryzysu zanotowano w aglomeracji poznańskiej (48\% w Poznaniu i 43\% w powiecie poznańskim) i w Lesznie (43\%). Największy wpływ kryzysu na popyt odnotowano ponownie w Kaliszu (aż 70\% firm, które odczuły skutki kryzysu, odnotowało spadek liczby zamówień). Wysokim odsetkiem przedsiębiorstw, które odnotowały spadek liczby zamówień, cechował się także Poznań (62\%). Najmniej skutki kryzysu w odniesieniu do popytu odczuło Leszno. W tym przypadku prawie $40 \%$ badanych wskazało na ograniczenie popytu, przy jednoczesnym wzroście popytu w przypadku $18 \%$ firm (por. ryc. 14 i 15). 


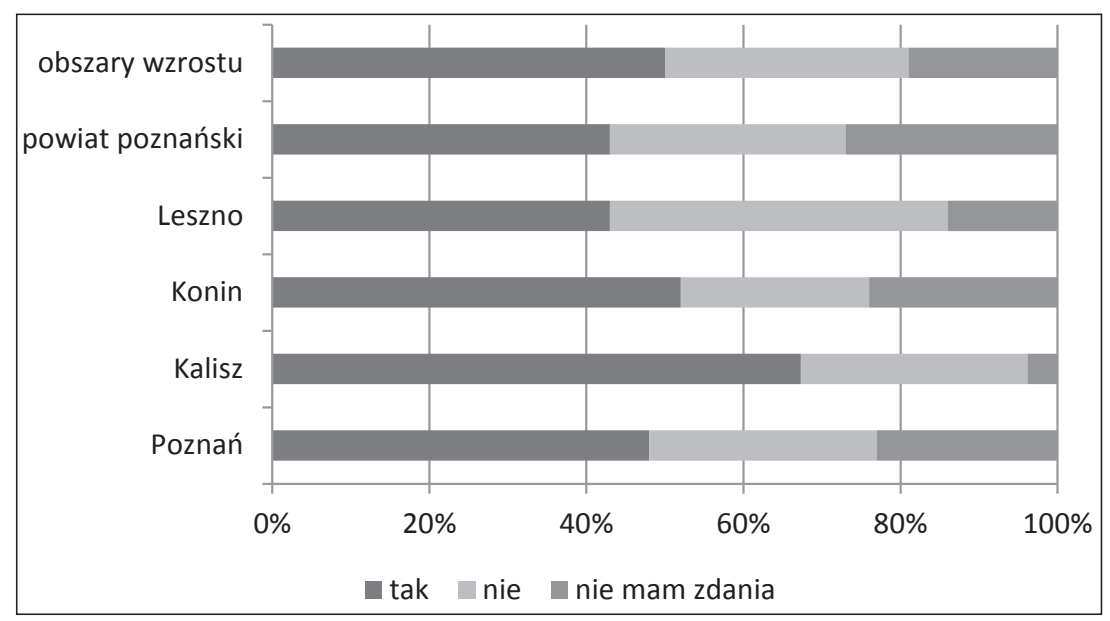

Ryc. 14. Odpowiedzi badanych firm na pytanie o wpływ kryzysu ekonomicznego na ich funkcjonowanie Źródło: opracowanie własne

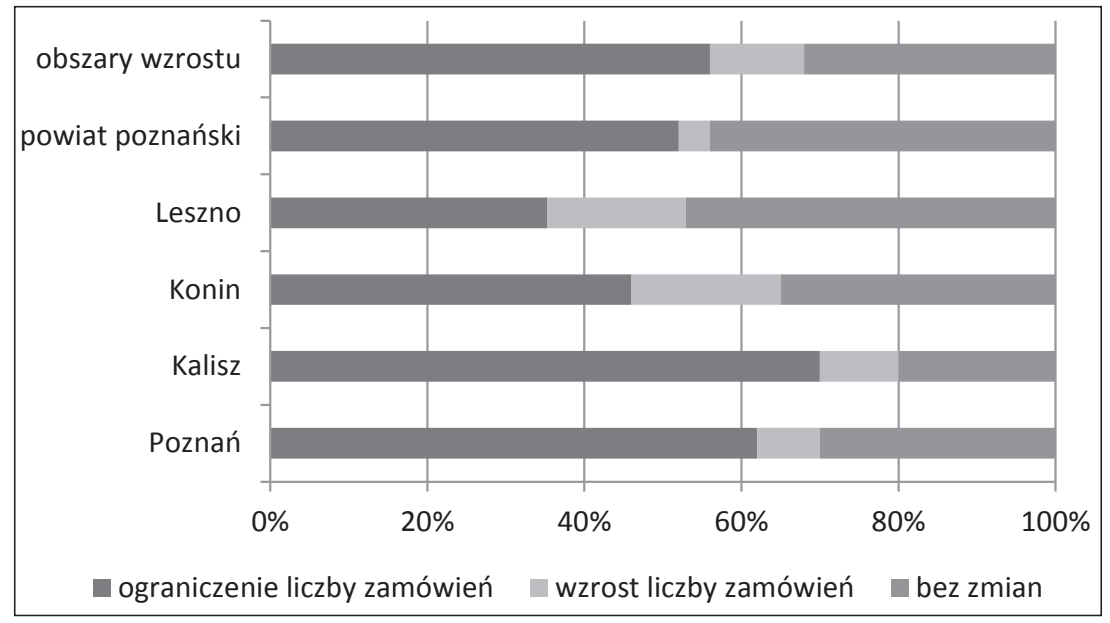

Ryc. 15. Wpływ kryzysu na popyt

Źródło: opracowanie własne

Ograniczenie liczby zamówień bezpośrednio przełożyło się na sytuację ekonomiczną badanych firm. Na obszarach wzrostu prawie 45\% badanych odnotowało pogorszenie kondycji ekonomicznej. Podobnie jak w poprzednim przypadku, największą wrażliwość na skutki kryzysu stwierdzono w Kaliszu, gdzie aż $60 \%$ badanych odczuło pogorszenie sytuacji finansowej firmy. Na pozostałych obszarach osłabienie kondycji ekonomicznej odczuło ok. $40 \%$ przedsiębiorstw. Tak jak w przypadku popytu, również i w kwestii kondycji ekonomicznej dla ok. 10\% firm z Konina, Leszna i Poznania czas kryzysu okazał się okresem pozytywnych zmian skutkujących poprawą kondycji gospodarczej (por. ryc. 16). 


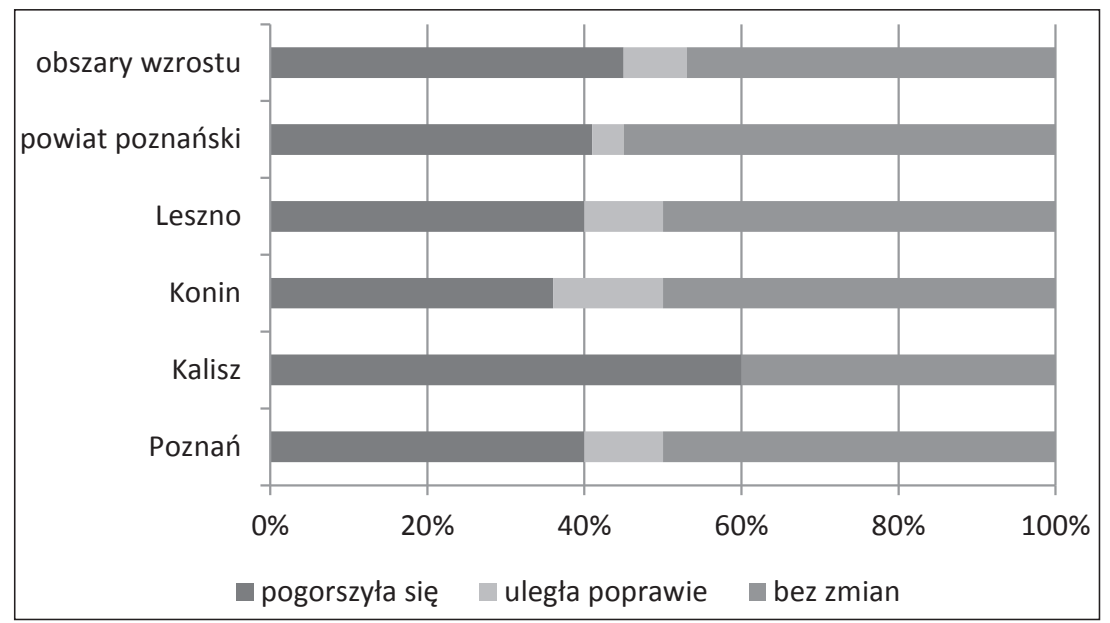

Ryc. 16. Wpływ kryzysu na kondycję ekonomiczną firmy

Źródło: opracowanie własne

Kryzys w małym stopniu wpłynął na wielkość zatrudnienia. Tylko w przypadku 20\% firm odnotowano zmniejszenie liczby pracowników. Przyczyną tego jest zdecydowana przewaga w badanej grupie mikroprzedsiębiorstw, zatrudniających niewielu pracowników. Jakiekolwiek ograniczenie zatrudnienia w takim przypadku zdecydowanie silniej wpłynęłoby na zdolność firmy do sprawnego funkcjonowania niż w przypadku większych przedsiębiorstw. Potwierdzeniem tej tezy jest fakt, że właśnie firmy w Kaliszu oraz w powiecie poznańskim, które charakteryzowały się największą przewagą mikroprzedsiębiorstw, w najmniejszym stopniu ograniczyły zatrudnienie pod wpływem kryzysu (por. ryc. 17).

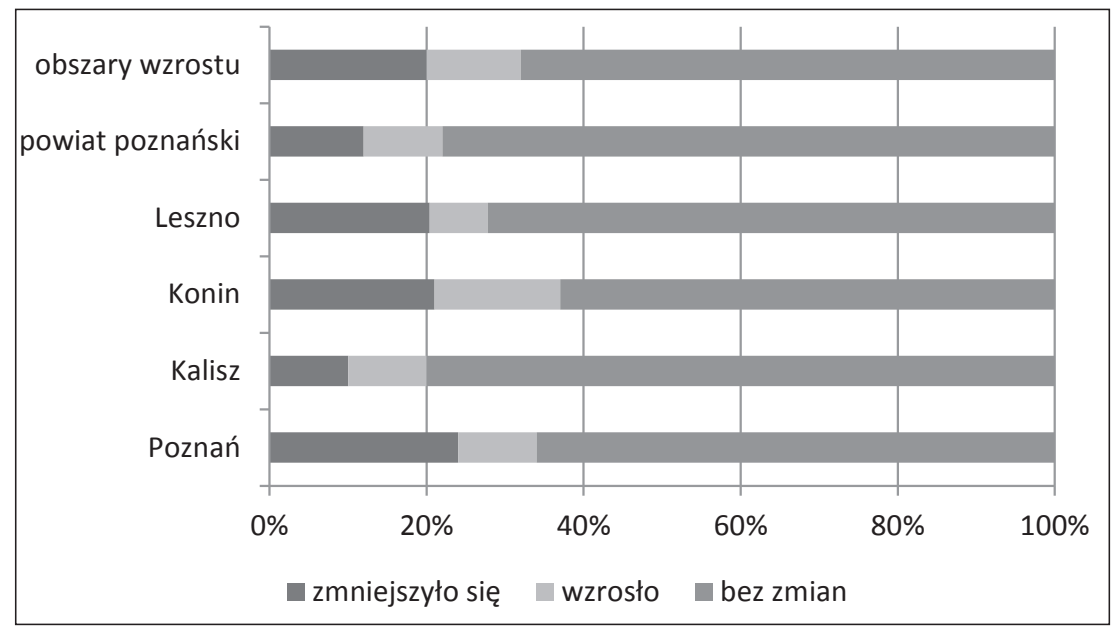

Ryc. 17. Wpływ kryzysu na zatrudnienie

Źródło: opracowanie własne 
Kryzys nie wpłynął również znacząco na zmianę zasięgu oddziaływania badanych firm. Ponad 90\% badanych nie odnotowało zmian w tym zakresie. Jego ograniczenie w największym stopniu odczuły przedsiębiorstwa z Kalisza i powiatu poznańskiego, natomiast rozszerzenie nastąpiło w przypadku firm z Leszna i Poznania (por. ryc. 18).

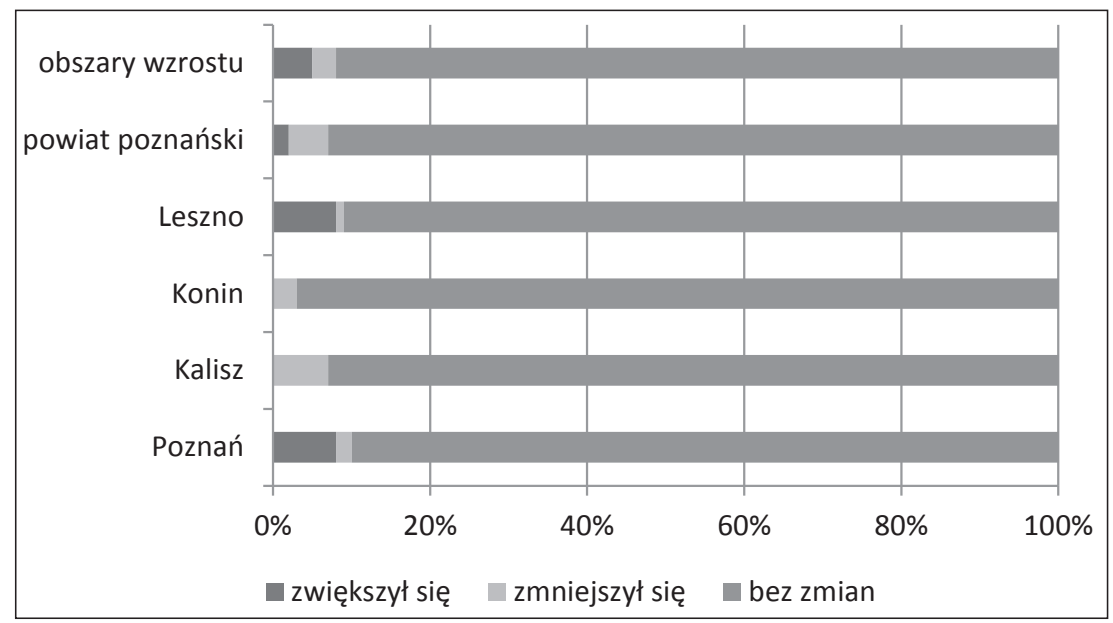

Ryc. 18. Wpływ kryzysu na zasięg oddziaływania firm

Źródło: opracowanie własne

Nie zdecydowano się także na zmianę oferty usługowej pod wpływem kryzysu. Ponad $80 \%$ badanych firm nie zmieniło nic w swojej ofercie. Nieliczne organizacje ( $9 \%$ ) były zmuszone do jej ograniczenia, a kolejne $8 \%$ zdecydowało się rozszerzyć zakres usług. Ponownie Leszno i Poznań były tymi obszarami, które odnotowały największy odsetek firm poszerzających ofertę (por. ryc. 19).

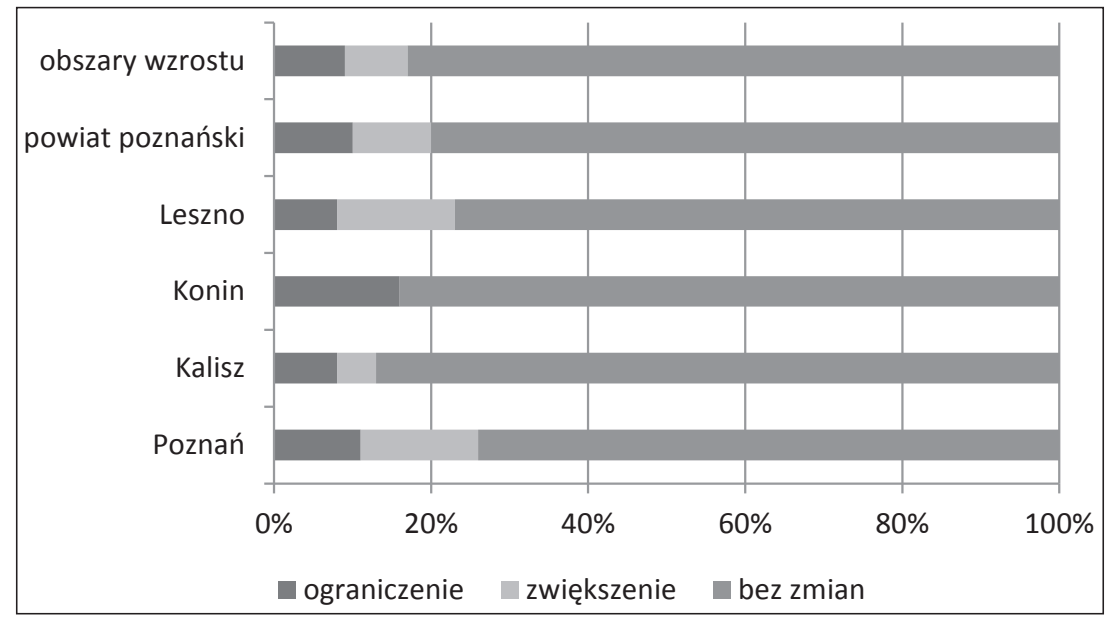

Ryc. 19. Wpływ kryzysu na ofertę usług

Źródło: opracowanie własne 
W niemal 70\% badanych firm kryzys gospodarczy nie przełożył się bezpośrednio na zmiany we współpracy z otoczeniem biznesu. W zdecydowanej większości badane firmy nie postrzegały więc kontaktów z instytucjami otoczenia biznesu jako drogi wyjścia z kryzysu. Jedynie w przypadku 23\% firm kryzys wpłynął na intensyfikację współpracy z instytucjami otoczenia biznesu, a $8 \%$ odnotowało nawet spadek korzystania z usług IOB. W tym zakresie nie odnotowano większych zmian pomiędzy badanymi obszarami.

\section{ANALIZA POPYTOWA OTOCZENIA BIZNESU}

Charakterystyka popytowa otoczenia biznesu uwzględnia: korzystanie z usług instytucji otoczenia biznesu przez badane przedsiębiorstwa (w podziale na poszczególne rodzaje IOB) oraz korzystanie z komercyjnych firm świadczących usługi biznesowe (w podziale na poszczególne rodzaje usług dla biznesu). Analiza prowadzona była w układzie: obszary wzrostu - obszary stagnacji gospodarczej oraz w podziale na poszczególne miasta i powiaty, wchodzące w skład obszarów wzrostu i stagnacji.

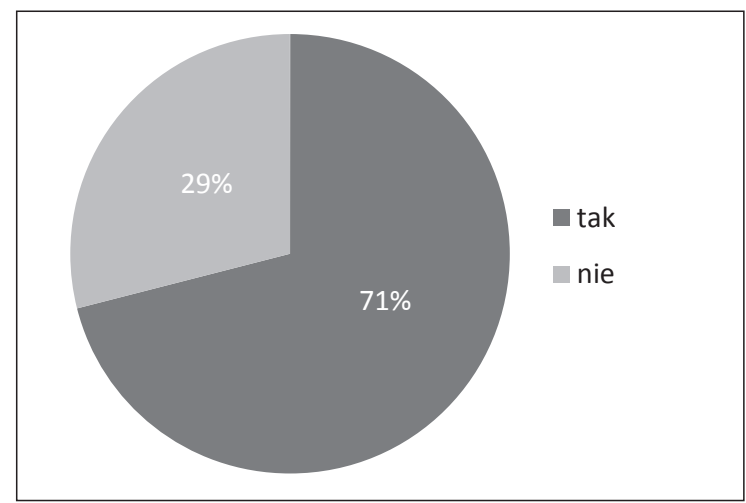

obszary wzrostu

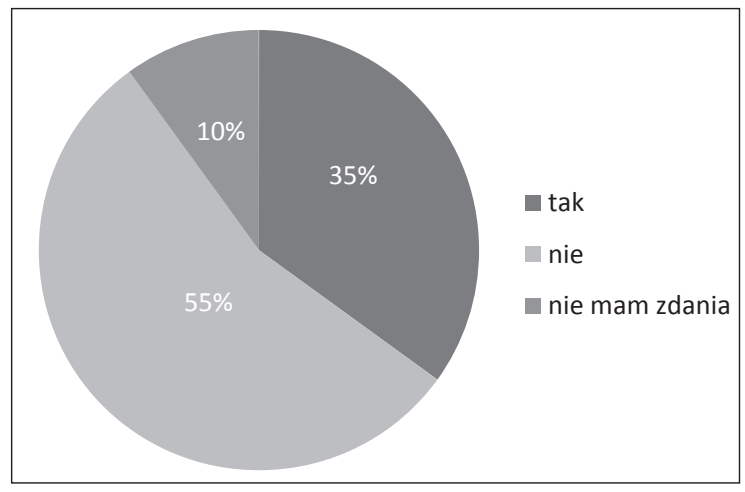

obszary stagnacji

Ryc. 20. Czy przedsiębiorstwo korzysta z usług otoczenia biznesu?

Źródło: opracowanie własne 
Badane przedsiębiorstwa w zdecydowanej większości korzystały z usług dla biznesu. Na obszarach wzrostu było to $71 \%$ badanych, a na obszarach stagnacji - 59\% (por. ryc. 20). $\mathrm{Na}$ obszarach wzrostu najwięcej z usług otoczenia biznesu korzystały firmy zlokalizowane w aglomeracji poznańskiej - Poznaniu i powiecie poznańskim. Najprawdopodobniej ma to związek z dostępnością tego rodzaju usług, która jest największa w dużych aglomeracjach miejskich. Zdecydowana większość takich usług w województwie wielkopolskim koncentruje się właśnie w Poznaniu i jego strefie podmiejskiej, stąd także tutaj największa jest ich dostępność. Firmy zlokalizowane na obszarach stagnacji znacznie rzadziej korzystały z usług otoczenia biznesu. Szczególnie niski odsetek przedsiębiorstw współpracujących z instytucjami i firmami świadczącymi tego rodzaju usługi wystąpił w powiecie pleszewskim - tylko nieco ponad 40\%. Nieco więcej przedsiębiorstw zadeklarowało współpracę w powiatach kaliskim (60\%) oraz słupeckim (ponad 70\%).

Wśród przedsiębiorstw korzystających z usług otoczenia biznesu zdecydowana większość deklarowała współpracę z komercyjnymi firmami wykonującymi takie usługi. Było to ok. $95 \%$ badanych na obszarach wzrostu i ok. $65 \%$ na obszarach stagnacji. Zdecydowanie mniej badanych przedsiębiorstw korzystało z usług oferowanych przez instytucje otoczenia biznesu. W tym przypadku ich odsetek wahał się od kilku do $20 \%$. Wśród usług instytucji otoczenia biznesu najpopularniejsze były usługi ośrodków szkoleniowo-doradczych (korzystało z nich nieco ponad $20 \%$ firm zlokalizowanych na obszarach wzrostu i ok. $10 \%$ firm z obszarów stagnacji). Podobne wyniki badań dotyczące współpracy firm z instytucjami otoczenia biznesu w południowej Polsce przedstawia Wach (Wach, 2008). Współpraca z pozostałymi instytucjami otoczenia biznesu dotyczyła ok. $10 \% \mathrm{w}$ przypadku instytucji finansowych, władz samorządowych oraz organizacji gospodarczych. Jeszcze mniej przedsiębiorstw współpracowało z instytucjami środowiska innowacyjnego - sferą B $+R$, parkami naukowymi i centrami transferu technologii (poniżej 5\% badanych). Słaba współpraca małych i średnich przedsiębiorstw z instytucjami naukowymi stanowi poważną barierę w rozwijaniu innowacyjności gospodarki regionu (Mizgajska, Wściubak 2009).

Wśród przedsiębiorstw, które zadeklarowały współpracę z firmami świadczącymi komercyjne usługi biznesowe, wszystkie współpracowały z bankami i innymi instytucjami pośrednictwa finansowego. Duża część z nich korzystała także z usług biur rachunkowych i księgowych oraz doradztwa podatkowego. Ok. 50\% badanych przedsiębiorstw korzystało z usług firm ubezpieczeniowych i agencji reklamowych. Zdecydowanie mniej organizacji współpracowało z kancelariami prawnymi, a także z firmami zajmującymi się doradztwem gospodarczym i technicznym oraz pozostałymi usługami dla biznesu (ok. 20\%).

Odnotowano nieznaczne różnice w strukturze komercyjnych firm dla biznesu, z których korzystały badane przedsiębiorstwa. Na wszystkich badanych obszarach korzystano głównie z usług finansowych. Na obszarach wzrostu częściej korzystano z usług reklamowych i marketingowych, obsługi prawnej oraz doradztwa gospodarczego i technicznego. Obszary stagnacji z kolei cechowały się relatywnie większym odsetkiem firm korzystających z usług księgowych i ubezpieczeniowych.

W większości badanych przedsiębiorstw nie odnotowano znaczących zmian we współpracy z otoczeniem biznesu w ostatnich pięciu latach. Na obszarach wzrostu brak 
zmian w tym zakresie deklarowało $64 \%$ badanych firm, a na obszarach stagnacji - 78\%. Jednocześnie 16\% firm na obszarach wzrostu i 9\% firm na obszarach stagnacji zwiększyło zakres współpracy w ostatnich pięciu latach, a odpowiednio 13\% i 7\% nawiązało nowe kontakty z instytucjami i firmami otoczenia biznesu. Tylko $7 \%$ badanych przedsiębiorstw na obszarach wzrostu i 6\% na obszarach stagnacji ograniczyło kontakty z otoczeniem biznesu w ostatnich pięciu latach (por. ryc. 21).

Najkorzystniejsze zmiany w zakresie współpracy z otoczeniem biznesu stwierdzono w Poznaniu i powiecie poznańskim. To właśnie w aglomeracji poznańskiej odnotowano największy odsetek przedsiębiorstw deklarujących zwiększenie zakresu dotychczasowej współpracy z instytucjami i firmami otoczenia biznesu. Relatywnie wysokim odsetkiem firm, które nawiązały nowe kontakty z otoczeniem biznesu, charakteryzował się Konin, co może wskazywać na proces rozwoju współpracy na tym obszarze. Współpraca z otoczeniem biznesu na obszarach stagnacji była zróżnicowana. Najkorzystniej sytuacja kształtowała się w powiecie kaliskim, gdzie relatywnie wysoki odsetek firm deklarował zwiększenie zakresu istniejącej współpracy oraz nawiązanie nowych kontaktów z instytucjami i firmami otoczenia biznesu. Otrzymane wyniki wskazują na wysoką dynamikę rozwoju sieci powiązań z instytucjami otoczenia biznesu w strefie peryferyjnej aglomeracji kaliskiej. Odwrotna sytuacja zachodzi w powiecie pleszewskim. Współpraca przedsiębiorstw z otoczeniem biznesu w tym powiecie, mimo że i tak słaba, została w ostatnich pięciu latach jeszcze bardziej ograniczona.

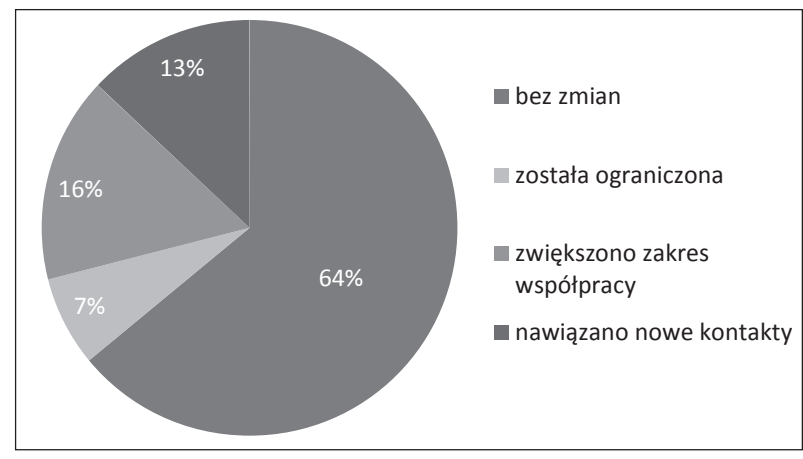

obszary wzrostu

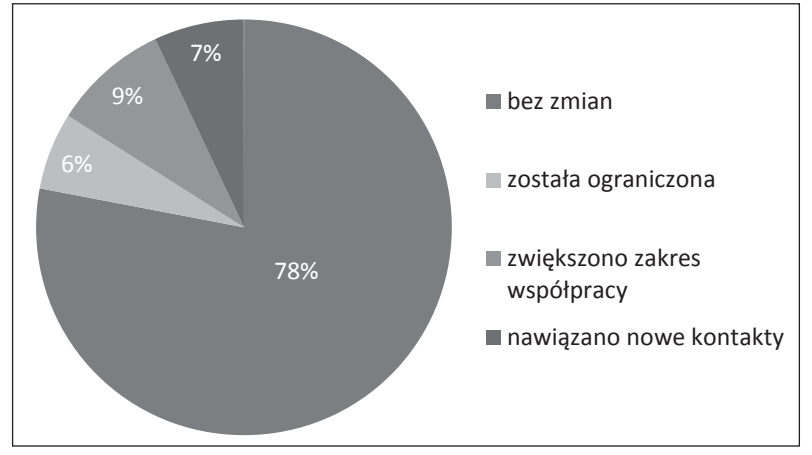

obszary stagnacji

Ryc. 21. Zmiany we współpracy z otoczeniem biznesu w ciągu ostatnich pięciu lat Źródło: opracowanie własne 
Te przedsiębiorstwa, które korzystały z usług instytucji i firm otoczenia biznesu, w większości pozytywnie oceniły ich działania. Pozytywną ocenę wystawiło $65 \%$ badanych firm na obszarach wzrostu. Na obszarach stagnacji odsetek ten był niższy i wynosił 46\%. Jednocześnie 30\% badanych na obszarach wzrostu i aż 37\% na obszarach stagnacji nie miało w tej kwestii zdania. Negatywnie usługi otoczenia biznesu oceniło 5\% firm z obszarów wzrostu i 17\% firm z obszarów stagnacji (por. ryc. 22). Najgorzej usługi otoczenia biznesu oceniły firmy z Kalisza i powiatu kaliskiego, z kolei najlepiej zostały one ocenione w aglomeracji poznańskiej.

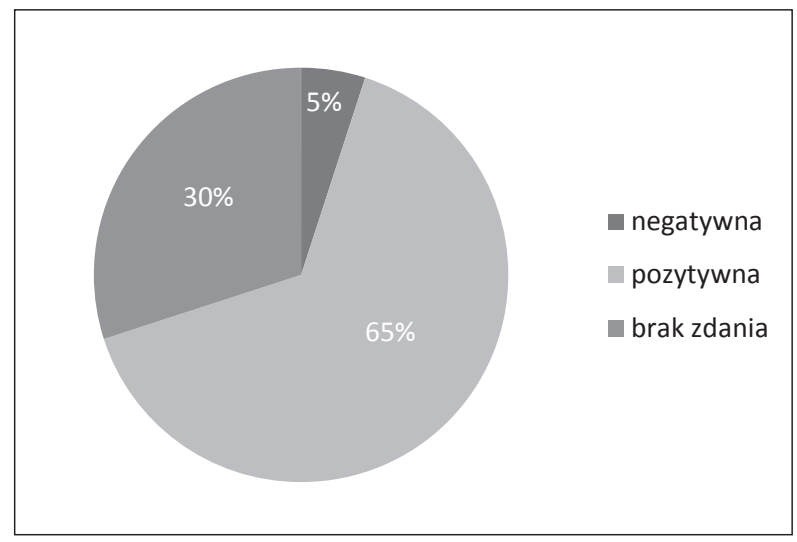

obszary wzrostu

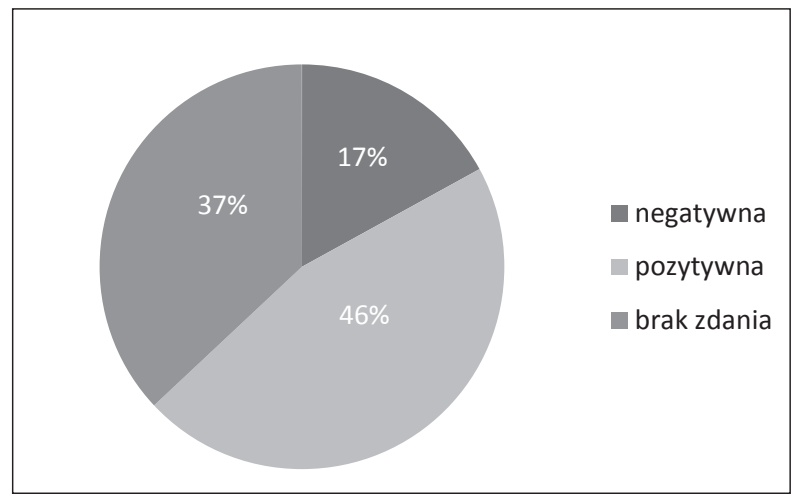

obszary stagnacji

Ryc. 22. Ocena instytucji i firm otoczenia biznesu

Źródło: opracowanie własne

Podsumowanie

Kryzys gospodarczy zapoczątkowany w 2008 roku w różnym stopniu dotknął uczestników rynku usług otoczenia biznesu w Wielkopolsce. Wpływ kryzysu odczuło $40 \%$ instytucji i 50\% komercyjnych firm wykonujących usługi dla biznesu. 
Instytucje otoczenia biznesu największy wpływ kryzysu odnotowały w odniesieniu do wielkości zgłaszanego popytu. W warunkach spowolnienia gospodarczego firmy coraz częściej rezygnowały z usług świadczonych zarówno przez instytucje tworzące środowisko innowacyjne, jak i organizacje gospodarcze (choć te ostatnie odczuły wpływ kryzysu na popyt w mniejszym stopniu). Mimo ograniczenia liczby zamówień, kryzys gospodarczy nie przełożył się znacząco na obniżenie kondycji ekonomicznej badanych instytucji środowiska innowacyjnego. Wynika to ze struktury finansowania działalności tych instytucji, która w znacznym stopniu pochodzi ze źródeł budżetu państwa. Nieco inaczej sytuacja ta kształtuje się w odniesieniu do organizacji gospodarczych, utrzymywanych w pewnym stopniu ze składek członkowskich. W ich przypadku aż połowa odczuła pogorszenie sytuacji ekonomicznej związanej z zaistniałym kryzysem gospodarczym. Pogorszenie to wywołało u 46\% instytucji próby dostosowania się do warunków zmniejszonego popytu, polegające na redukcji zatrudnienia lub rezygnacji ze współpracy z pracownikami zewnętrznymi. Kryzys w różnym stopniu wpłynął na sieć powiązań i współpracy instytucji otoczenia biznesu. W przypadku połowy z nich nastąpiło rozszerzenie tej współpracy o nowych partnerów albo zwiększenie jej zakresu. Względnie stały i odporny na kryzys gospodarczy okazał się być zasięg oddziaływania badanych instytucji.

Także w przypadku komercyjnych firm wykonujących usługi dla biznesu największy wpływ kryzysu gospodarczego zidentyfikowano w zakresie zgłaszanego popytu - zauważyło go ok. $60 \%$ badanych przedsiębiorstw. W przypadku komercyjnych firm spadek popytu bezpośrednio przełożył się na pogorszenie ich kondycji ekonomicznej (odczuła je niemal połowa badanych). W przypadku przedsiębiorstw świadczących usługi biznesowe nie zadziałał jednak mechanizm dostosowawczy związany z ograniczeniem zatrudnienia. Stało się tak dlatego, że są to zwykle mikroprzedsiębiorstwa z niewielką liczbą pracowników, w których redukcja zatrudnienia mogłaby nawet uniemożliwić ich funkcjonowanie. Kryzys nie wpłynął natomiast na zasięg oddziaływania, ofertę usług czy zakres współpracy komercyjnych firm.

Zmiany sytuacji gospodarczej spowodowane kryzysem nie oddziałały również znacząco na zmiany relacji przedsiębiorstw z otoczeniem biznesu. Najkorzystniejsze zmiany w tym zakresie, polegające na zwiększeniu sieci współpracy z otoczeniem biznesu, odnotowano na obszarze aglomeracji poznańskiej, cechującej się największym poziomem dostępności do tego rodzaju usług.

Kryzys gospodarczy nie przełożył się w istotny sposób na zmiany na rynku usług dla biznesu, choć wydaje się, że w okresie spowolnienia gospodarczego współpraca z instytucjami i firmami otoczenia biznesu mogłaby służyć poprawie sytuacji przedsiębiorstw, np. dzięki doradztwu, dodatkowym szkoleniom czy pomocy finansowej oferowanej przez instytucje o charakterze parabankowym. Wiąże się to zapewne z ciągle jeszcze relatywnie słabą rolą, jaką instytucje otoczenia biznesu odgrywają w rozwoju przedsiębiorstw w całym kraju. Ważną kwestią jest także rola otoczenia biznesu, a w szczególności środowiska innowacyjnego w podnoszeniu konkurencyjności polskiej gospodarki z pozostałymi krajami UE (Dołzbasz, 2009). W tym zakresie konieczne jest zwiększanie udziału wyrobów zaawansowanych technologicznie, a to możliwe jest tylko dzięki efektywnej współpracy między instytucjami otoczenia biznesu oraz na linii instytucje - przedsiębiorstwa. 


\section{Literatura \\ References}

Aydalot, P., Keeble, D. (1988). High technology industry and innovative environments: The European expierence. London: Routledge.

Bereza, J. (2013). Wpływ kryzysu finansowego na polski rynek pracy. W: Wspótczesne zagadnienia i problemy ekonomiczne i spoleczne. Kraków, 83-114.

Chmielewski, R., Stryjakiewicz, T., Twardowska, J., Waloszczyk, J. (2001). Innowacyjność przemysłu i jej zróżnicowanie w nowym układzie wojewódzkim. W: T. Czyż (red.). Zróżnicowanie społeczno-gospodarcze w nowym uktadzie terytorialnym. Biuletyn KPZK. Warszawa: PAN 197, 59-102.

Chojnicki, Z. (1999). Uwarunkowania rozwoju regionu nadgranicznego. Koncepcje i założenia teoretyczne. W: Z. Chojnicki. Podstawy metodologiczne i teoretyczne geografii. Poznań: Bogucki Wydawnictwo Naukowe, 355-380.

Daszkowska, M. (1998). Ustugi. Produkcja, rynek, marketing. Warszawa: Wydawnictwo Naukowe PWN.

Doloreux, D. (2002). What we should know about regional systems of innovation. Technology in society, 24 (3), 243-263.

Dołzbasz, S. (2009). Instytucje otoczenia biznesu oraz jednostki sfery B+R na obszarze województwa dolnośląskiego. W: Endo- $i$ egzogeniczne determinanty obszarów wzrostu $i$ stagnacji $w$ województwie dolnośląskim w kontekście Dolnośląskiej Strategii Innowacji DAWG. Wrocław: Urząd Marszałkowski Województwa Dolnośląskiego, 64-85.

Dominiak, J. (2006). Struktura i organizacja otoczenia biznesu w aglomeracji poznańskiej. Poznań: Bogucki Wydawnictwo Naukowe.

Gorzelak, G. (red.) (2009). Geografia polskiego kryzysu. Kryzys peryferii czy peryferia kryzysu. Warszawa: Regional Studies Association. Sekcja Polska.

Illeris, S. (1989). Services and regions in Europe. Aldershot: Avebury.

Illeris, S. (1994). Proximity between service producers and service users. Tijdrschrift voor Economische en Sociale Geografie, 85 (4), 294-302.

Illeris, S. (1997). The changing location of service activities in the Copenhagen region. Geografisktidsskrift, 97, 120-131.

Lehner, P., Todtling, F., Trippl, M. (2006). Innovation in knowledge intensive industries. The nature and geography of knowledge links. European Planning Studies, 14 (8), 1035-1058.

Markiewicz, J. (2007). Wpływ instytucji wsparcia na rozwój kooperacji i innowacyjność przedsiębiorstw w województwie zachodniopomorskim. W: Innowacje, przedsiębiorczość i gospodarka oparta na wiedzy. Zeszyty Naukowe, 453. Ekonomiczne problemy usług, 8. Uniwersytet Szczeciński, 133-145.

Matusiak, K.B. (2007). Systemy wsparcia przedsiębiorczości i procesów innowacyjnych. W: Innowacje, przedsiębiorczość i gospodarka oparta na wiedzy. Zeszyty Naukowe, 453. Ekonomiczne problemy usług, 8. Uniwersytet Szczeciński, 145-155.

Mizgajska, H., Wściubiak, Ł. (2009). Współpraca małych i średnich przedsiębiorstw o zróżnicowanym zaawansowaniu technologicznym z nauką. W: M. Bąk, P. Kulawczuk (red.). Warunki skutecznej wspótpracy pomiędzy nauka a przedsiębiorstwami. Warszawa: Instytut Badań nad Demokracją i Przedsiębiorstwem Prywatnym, 141-154.

Nowosielska, E. (2000). Sektor usług w aglomeracji warszawskiej 1992-1997: przemiany strukturalne i tendencje rozwoju. Dokumentacja Geograficzna, 17. Warszawa: IGiPZ PAN.

Orłowski, W., Pasternak, R., Flaht, K., Szubert, D. (2010). Procesy inwestycyjne i strategie przedsiębiorstw w czasach kryzysu. Warszawa.

Todtling, F., Lehner, P., Kaufmann, A. (2008). Do different types of innovation rely on specific kinds of knowledge interactions. Institute of Regional Development and Environmnet. Wien. Pozyskano $\mathrm{z}$ www.epub.wu.ac.at 
Wach, K. (2008). Regionalne otoczenie matych i średnich przedsiębiorstw. Kraków: Wydawnictwo Uniwersytetu Ekonomicznego w Krakowie.

Zioło, Z. (2013). Uwarunkowania rozwoju przedsiębiorczości w warunkach kryzysu gospodarczego. Przedsiębiorczość-Edukacja, 9, 10-33.

Joanna Dominiak, adiunkt w Zakładzie Analizy Regionalnej Instytutu Geografii Społeczno-Ekonomicznej i Gospodarki Przestrzennej Uniwersytetu im. Adama Mickiewicza w Poznaniu. Zainteresowania naukowe koncentrują się wokół roli innowacyjności w kształtowaniu gospodarki opartej na wiedzy, wpływu otoczenia biznesu na rozwój regionów oraz przemian w strukturze usług.

Joanna Dominiak is an assistant professor in the Department of Regional Analysis in the Institute of Socio-Economic Geography and Spatial Management at the Adam Mickiewicz University in Poznan. Her academic interests include the role of innovation in the development of the knowledge-based economy; the impact of the business environment on the development of regions; and changes in the structure of services.

\section{Adres/address:}

Uniwersytet im. A. Mickiewicza w Poznaniu

Instytut Geografii Społeczno-Ekonomicznej i Gospodarki Przestrzennej

Zakład Analizy Regionalnej

ul. Dzięgielowa 27, 61-680 Poznań, Polska

e-mail: dominiak@amu.edu.pl 